\title{
Article
}

\section{Mobile Phones, Institutional Quality And Entrepreneurship in Sub-Saharan Africa}

Asongu, Simplice, Nwachukwu, Jacinta Chikaodi and Orim, StellaMaris

Available at http://clok.uclan.ac.uk/25151/

Asongu, Simplice, Nwachukwu, Jacinta Chikaodi ORCID: 0000-0003-2987-9242 and Orim, Stella-Maris (2018) Mobile Phones, Institutional Quality And Entrepreneurship in Sub-Saharan Africa. Technological Forecasting and Social Change, 131 . pp. 183-203. ISSN 0040-1625

It is advisable to refer to the publisher's version if you intend to cite from the work. http://dx.doi.org/10.1016/j.techfore.2017.08.007

For more information about UCLan's research in this area go to http://www.uclan.ac.uk/researchgroups/ and search for <name of research Group>.

For information about Research generally at UCLan please go to http://www.uclan.ac.uk/research/

All outputs in CLoK are protected by Intellectual Property Rights law, including Copyright law. Copyright, IPR and Moral Rights for the works on this site are retained by the individual authors and/or other copyright owners. Terms and conditions for use of this material are defined in the policies page. 

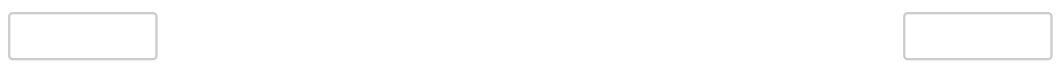

$\square$ 


\section{A G D I Working Paper}

\section{$\mathrm{WP} / 16 / 044$}

\section{Mobile phones, Institutional Quality and Entrepreneurship in Sub-Saharan}

\section{Africa}

Forthcoming: Technological Forecasting and Social Change

\section{Simplice A. Asongu}

African Governance and Development Institute,

P.O. Box 8413, Yaoundé,

Cameroon

E-mail: asongusimplice@yahoo.com

/ asongus@afridev.org

\section{Jacinta C. Nwachukwu}

School of Economics, Finance and Accounting,

Faculty of Business, and Law

Coventry University

Priory Street, Coventry, CV1 5DH, UK

Email:jacinta.nwachukwu@coventry.ac.uk

\section{Stella-Maris Orim}

School of Engineering, Environment and Computing,

Coventry University

Priory Street, Coventry, CV1 5DH, UK

Email: aa7863@coventry.ac.uk 
Research Department

Mobile phones, Institutional Quality and Entrepreneurship in Sub-Saharan Africa

\author{
Simplice A. Asongu, Jacinta C. Nwachukwu \& Stella-Maris Orim
}

November 2016

\begin{abstract}
This study investigates whether mobile phone penetration modulates the effect of different indicators of governance on some indicators of the ease of doing business in Sub-Saharan Africa with data from the period 2000-2012 by employing the Generalised Method of Moments. Three broad concepts of governance are explored: (i) political (comprising voice \& accountability and political stability/no violence), (ii) economic (involving government effectiveness and regulation quality) and (iii) institutional (including corruption-control and rule of law). Ten dimensions of entrepreneurship are considered. Two main findings are established with respect to the net effects of the interaction between mobile phones and governance dynamics. They are (1) reduced cost of business start-up procedure, the time to build a warehouse and the time to resolve an insolvency and (2) increased time to enforce a contract, to register a property and to prepare and pay taxes. Implications for theory and policy are discussed. Some of the engaged policy implications include the following. (i) Measures on how to leverage on the potential of mobile phone penetration for entrepreneurship opportunities by addressing challenge of access to and affordability of mobile phones on the one hand and on the other hand, improving on the role of the mobile phone as a participative interface between emerging entrepreneurs and governance. (ii) The relevance of the mobile phone in mitigating information asymmetry between entrepreneurs and government institutions, notably by: reducing government inefficiency (which potentially represents an additional cost to doing business) and decreasing informational rents, bureaucracy and transaction costs.
\end{abstract}

JEL Classification: L59; L98; O10; O30; O55

Keywords: Entrepreneurship; Knowledge Economy; Development; Africa

\title{
Acknowledgement
}

The authors are indebted to the editor and reviewers for constructive comments. 


\section{Introduction}

This study investigates whether mobile phone penetration ${ }^{1}$ modulates the effect of different indicators of governance on some indicators of the ease of doing business in SubSaharan Africa $(\mathrm{SSA})^{2}$. At least three reasons motivate the inquiry.

First, there is a high potential for information and communication technology (ICT) penetration in Africa given that high-end markets in Asia, Europe and North America are experiencing stabilization in the growth of ICTs like mobile phones (see Penard et al., 2012; Asongu, 2015). Hence, policy reforms could be leveraged on the mobile phone penetration potential to address economic concerns like job creation in the African continent.

Second, entrepreneurship for job creation has been documented as one of the principal remedies for Africa's growing population and corresponding unemployment (Tchamyou, 2016; Daouda et al., 2016). In essence, the current generation is witnessing the most significant demographic transformation and Africa is playing a substantial role in the transition. To be sure, the continent's population has been projected to double by 2036; representing about twenty percent of the world total (UN, 2009; Asongu, 2013). Unemployment, especially among youth, has been documented as one of the most important challenges of this demographic transition inter alia: criminal activities and engagement in armed conflicts (Brixiova et al., 2015; AERC, 2014). The continent has been endowed with the fastest growing youth demography, which represents about 20 percent of its population. The percentage of population between the ages of 15 and 24 may represent sub-optimal and negative externalities if jobs are not available to accommodate this anticipated demographic shift.

Third, in the light of the above policy concerns, the literature has not substantially addressed linkages between ICT and entrepreneurship in Africa. The study closest to this relationship is Tchamyou (2016) which investigated the role of the knowledge economy in African business. It concluded that the four dimensions of the World Bank's knowledge economy index played a fundamental role in driving the starting and the continuation of business in Africa. The conclusion of Tchamyou is broadly consistent with the extant

\footnotetext{
${ }^{1}$ Throughout this study, the terms "mobile', 'mobile telephony', 'mobile phones' and 'mobile phone penetration' are used interchangeably.

${ }^{2}$ Consistent with Naudé (2010) and Brixiova et al. (2015), entrepreneurship is defined in this study as the resources and processes whereby individuals can use market avenues to create new enterprises. The terms 'entrepreneurship' and 'doing business' are used interchangeably throughout the study.
} 
theoretical and empirical literature (which is engaged in Section 2) on the importance of knowledge spillovers in entrepreneurship (Acs et al., 2013; Hayter 2013; Kuada, 2014; Ghio et al., 2015; Afutu-Kotey et al., 2017), notably: the relevance of social media in promoting entrepreneurship (McCann \& Barlow, 2015; Jones et al., 2015; Wang, 2016); the employment of social entrepreneurship to boost technology (Mulloth et al., 2016); knowledge sharing for the success of entrepreneurship (Allen et al., 2016); innovating the mobile phone for entrepreneurship (Asongu \& Biekpe, 2017) and linkages between ICT, openness and entrepreneurship (Asongu \& Nwachukwu, 2018).

We extend this literature by assessing whether mobile phone penetration modulates the effect of different indicators of governance on some indicators of the ease of doing business. Whereas governance is the main independent variable, mobile phone penetration is considered as a policy variable because in the modelling exercise, it modulates the effect of governance on entrepreneurship. The motivation to include governance indicators builds on a stream of recent literature on the relevance of good governance in addressing sustainable development challenges such as unemployment in Africa. Theoretically, the quality of governance has been increasingly linked with improving: (i) the quality of life and the efficient allocation of resources (Fosu, 2013; Anyanwu \& Erhijakpor, 2014), (ii) the situation of the deprived elderly (Fonchingong, 2014) and (iii) the foundation for changes in society (Fosu, 2015a, 2015b; Efobi, 2015; Ajide \& Raheem, 2016).

In addition to the above justification for harnessing good governance and mobile phones for entrepreneurship in Sub-Saharan Africa (SSA), there has been caution in scholarly circles not to consider the mobile phone as a silver bullet of development (Mpogole et al., 2008, p. 71). To enhance opportunities for policy implications, three main governance categories are employed, namely: (i) political governance (involving political stability/no violence and voice and accountability); (ii) economic governance (covering government effectiveness and regulation quality) and (iii) institutional governance (comprising corruptioncontrol and the rule of law). "Political governance is defined as the election and replacement of political leaders. Economic governance is the formulation and implementation of rules that enable the delivery of public goods and services. Institutional governance is the respect of the state and citizens for institutions that govern interactions between them" (Asongu \& Nwachukwu, 2016a, p. 2).

In the light of the above, the primary contribution of this paper is to complement the existing macroeconomic and institutional literature on how entrepreneurship can be boosted in 
less developed countries. The inquiry combines the issues raised by assessing how the potential for mobile phone penetration (discussed in the second paragraph) can modulate the effect of governance on entrepreneurship (discussed in the third paragraph) in order to address the identified gap in the third strand (covered in the fourth paragraph). Any boost in entrepreneurship which could potentially address contemporary policy challenges in the continent is discussed in the second strand. Therefore, this investigation seeks to address the following research question: does mobile phone penetration modulate the effect of different indicators of governance on some indicators of the ease of doing business in SSA? Such positioning substantially deviates from the microeconomic literature on employing technology in entrepreneurial opportunities. This literature is discussed in the section that follows. The remainder of the paper is presented as follows. The theoretical underpinnings and related literature are dicussed in Section 2. The data and methodology are covered in Section 3. Section 4 presents the empirical results and corresponding discussion while Section 5 concludes with suggestions on future research directions.

\section{Theoretical Underpinnings and Related Literature}

The relevance of knowledge and ICT in economic prosperity has been the subject of much scholarly concern (Asongu et al., 2016). The literature is consistent with a two-way causality flow between economic development and knowledge. Compared to the neoclassical growth theories which acknowledged technology and know-how as public goods and services which are strictly exogenous to the economic system, both the neo-Schumpeterian and endogenous interpretations of economic development are the basis for new economic development (Howells, 2005). According to these underlying new growth underpinnings, progress in technology is the result of an immediate investment by citizens via resource mobilizations which are critically related to human resources (Romer, 1990).

As recently documented by Brixiova et al. (2015), the relevance of productive entrepreneurship for economic development as well as variations in the types of entrepreneurship across nations have already been substantially studied (also see Baumol, 1968, 1990). According to the authors, both empirical and theoretical literature on factors affecting entrepreneurship in developing countries in general and Africa in particular are comparatively scarce. Some papers in this strand include: Baumol (2010); Naudé (2008, 2010); Leff (1979); Brixiova (2010, 2013) and Gelb et al. (2009). 
The policy concern for youth unemployment in Africa has already been discussed in the introductory section. Entrepreneurship is a means by which this policy syndrome can be addressed. The following principal causes of youth unemployment have been documented in the literature, inter alia: changes in population settings (Korenman \& Neumark, 2000); development of human resources (O’Higgins, 2001); social capital (like networks and family background) (Coleman, 1988); mismatches in geography and skills (2003) and idiosyncratic specificities and structural variations of economies (Peterson \& Vroman, 1992).

Alagidede (2008) has established that entrepreneurship in Africa may often be too risky. Eifert et al. (2008) investigated the cost of doing business on the continent and concluded that existing estimates undervalue the comparative performance of African corporations. A legal view of changes in and challenges of doing business in South Africa was provided by Taplin and Synman (2004). The intensity by which trade influences business cycle synchronization is assessed by Tapsoba (2010) who has established evidence of some causal effect. The founding and progress of entrepreneurs in East Africa has been investigated by Khavul et al. (2009) who concluded that substantial community and family ties are employed by entrepreneurs to grow their businesses. Furthermore, members of the family also serve as a reliable and flexible source of cheap labour which is relevant in mitigating costs when enterprises are at initial stages of development (Kuada, 2009). The practical and theoretical insights into the role of foreign direct investment in social responsibility in developing countries were considered by Bardy et al. (2012). Paul et al. (2010) examined the influence of labour regulation externalities on the cost of doing business to establish that the indicators of doing business from the World Bank do not provide a complete perspective on the employment of workers.

The intension to become an entrepreneur by Ethiopian undergraduate students was scrutinised by Gerba (2012) to conclude that their desire to become entrepreneurs increased with lessons and studies on the doing of business. Singh et al. (2011) investigated the drivers behind the decision to become entrepreneurs by Nigerian women and found the following motivations: the availability of (i) family capital and (ii) internal and educational environments which are characterised by economic deregulation and social recognition that is internally-oriented.

The relationship between youth entrepreneurship and financial literacy was examined by Oseifuah (2010) in South Africa to establish that financial literacy is a critical determinant of entrepreneurial skills. Mensah and Benedict (2010) studied the long-run consequences of 
entrepreneurship "training" to conclude that poverty-reducing hand-outs from the government only lead to short-run impacts, with ambiguous externalities on violent protests and demonstrations. Conversely, the availability of training and opportunities for entrepreneurship provide small enterprises with avenues for improving their businesses which eventually mitigate poverty. The above narratives are broadly in line with policy reports (see Leke et al., 2010; Ernst \& Young, 2013) and literature surveys (Kuada, 2015) on the challenges to entrepreneurship in Africa.

In more contemporary African entrepreneurship literature, Tchamyou (2016) investigated the role of the knowledge economy in doing business, whereas Asongu and Tchamyou (2016) evaluated the influence of entrepreneurship in the knowledge economy. An interesting finding from the two studies is that causality flows in both directions, notably from the knowledge economy to entrepreneurship and from entrepreneurship to knowledge economy. As emphasised in the introduction, the present inquiry builds on the underlying literature to assess whether mobile phone penetration modulates the effect of different indicators of governance on some indicators of the ease of doing business in SSA ${ }^{3}$.

Contemporary literature on the use of technology for entrepreneurial activities has included: emphasis on a series of innovations in entrepreneurship which are continuously improving because of financial resources and novel skills (Best, 2015); opportunity discovery and opportunity creation within the perspective of disruptive innovation (Wan et al., 2015; Hang et al., 2015), opportunities of entrepreneurship from an ageing population (Kohlbacher et al., 2015) and evolving ecosystems (Overholm, 2015), identification of opportunities by research collaborators (McKelveyet al., 2015) and scientific entrepreneurs (Maine et al., 2015) and technological advancements offering new opportunities owing to the road-mapping of patents (Jeong \& Yoon, 2015). This investigation also complements a stream of technology management literature on the consequences of emerging technologies, particularly: on the relevance of mobile phones in social change and development (Cozzens, 2011; Mira \& Dangersfield, 2012; Brouwer \& Brito, 2012; Islama \& Meadeb, 2012; Thakar, 2012; Alkemade \& Surrs, 2012; Gupta \& Jain, 2012; Sonne, 2012; Amankwah-Amoah, 2015, 2016; Amankwah-Amoah \& Sarpong, 2016).

The theoretical underpinning motivating the study is the institutions theory. According to the theory, institutions (i.e. a composition of formal norms and informal rules and their

\footnotetext{
${ }^{3}$ The mobile phone is used as a policy variable or as a grease/facilitator for the effect of governance on entrepreneurship. This is essentially why in the computation of net effects, the unconditional effect of governance and interactive effects (of governance and mobile phones) are used.
} 
enforcements) are relevant in elucidating the behaviour of entrepreneurs and firms. Accordingly, good governance provides enabling conditions for entrepreneurship or doing of business. This theoretical underpinning is consistent with the broad stream of literature on the subject, notably: (i) the relevance of formal institutions in enabling firms to reduce undue costs and risks in the conduct of market transactions (Meyer et al., 2009); (ii) institutional quality in organisational frameworks (Scott, 2001, 2002) and structures (Myers \& Rowan, 1977); (iii) firms' responses to institutional processes for strategic purposes (Oliver, 1991; Peng, 2003a, 2013b), sustainable competitive advantage (Oliver, 1997) and (iv) value creation through mergers and acquisitions (Du \& Boateng, 2015). Having clarified the theoretical underpinning on the relationship between institutions and doing business, it is important to engage the theoretical role of mobile phones in modulating governance.

We briefly summarise the literature on the relationship between mobile phones and governance. In accordance with Hellstrom (2008), the mobile phone as an ICT can be used to improve governance because it, among others: facilitates transparency, openness and the flow of information between various departments of government and institutions within a given country. According to the underpinnings, information decentralization through enhanced mobile phone networks mitigates opportunities for poor governance. While the position accords with a bulk of the empirical literature on the relationship between ICT and governance (Suarez, 2006; Boulianne, 2009; Diamond, 2010; Grossman et al., 2014), it is also important to note that there is a contending strand which maintains that collective violent action can be facilitated by ICT (Breuer et al., 2012; Pierskalla \& Hollenbach, 2013; Weidmann \& Shapiro, 2015; Manacorda \& Tesei, 2016). In the light of this background, the following hypothesis is tested in the empirical section.

Hypothesis: mobile phone penetration modulates the effect of different indicators of governance on some indicators of the ease of doing business.

In the light of above hypothesis, governance entails three dimensions: (i) political (comprising voice \& accountability and political stability/no violence), (ii) economic (involving government effectiveness and regulation quality) and (iii) institutional (including corruptioncontrol and rule of law). Ten dimensions of entrepreneurship or doing business are also considered (see Section 3.1). The hypothesis is investigated by computing the net effect of the 
modulating role of the mobile phone on the effect of governance on different doing business indicators.

Considering the substantially documented positive relationship between ICT and good governance, it is reasonable to hypothesise that the mobile phone can modulate the effect of governance on conditions for entrepreneurship. The intuition motivating the perspective that mobile phones can improve governance for better environments for doing business typically builds on the role of ICT in reducing information asymmetry (between government institutions and entrpreneurrs) that may be associated with the creation and running of enterprises. In summary, ICT-driven governance can provide conducive situations that mitigate informational rents which limit the doing of business. This intuition is broadly consistent with the theoretical underpinning of increasing financial allocation efficiency by means of information sharing mechanisms like public credit registreies and private credit bureaus (see Tchamyou \& Asongu, 2017). In the same vein, the mobile phone can serve as an informaion sharing medium that enhances efficiency in the doing of business.

\section{Data and Methodology}

\subsection{Data}

The study investigates an unbalanced panel of 48 countries in SSA with data from World Development Indicators (WDI) and World Governance Indicators (WGI) of the World Bank for the period 2000-2012 $2^{4}$. The adopted periodicity is based on data availability constraints whereas the scope of SSA is in line with the motivation of the study. Consistent with recent entrepreneurship literature (Tchamyou, 2016; Asongu \& Tchamyou, 2016), ten dependent variables on entrepreneurship are used, namely: (i) cost of business start-up procedure; (ii) procedure to enforce a contract; (iii) start-up procedures to register a business; (iv) time required to build a warehouse; (v) time required to enforce a contract; (vi) time required to register a property; (vii) time required to start a business; (viii) time to export; (ix) time to prepare and pay taxes and $(\mathrm{x})$ time to resolve an insolvency. A decreasing tendency in these variables implies a positive condition for entrepreneurship.

\footnotetext{
${ }^{4}$ It is important to note that an unbalanced panel translates to the presence of missing observations for some variables. There are currently only 49 countries in Sub-Saharan Africa. We have engaged 48 with the exception of South Sudan for which data is not available before 2011. The other five African countries from North Africa which are not included are: Morocco, Tunisia, Egypt, Libya and Algeria.
} 
Six governance variables from three main categories are employed, namely: (i) political governance (involving political stability/no violence and voice and accountability); (ii) economic governance (covering government effectiveness and regulation quality) and (iii) institutional governance (comprising corruption-control and the rule of law). These governance indicators which were abstracted from Kaufmann et al. (2010) have been employed in recent institutional literature (see Gani, 2011; Yerrabit \& Hawkes, 2015; Andrés et al., 2015; Oluwatobi et al., 2015; Amavilah et al., 2017). The mobile phone penetration rate (per 100 people) is used a policy independent variable.

In accordance with Tchamyou (2016), five control variables are adopted, namely: Gross Domestic Product (GDP) growth; population growth; foreign direct investment; private domestic credit and foreign aid. Theoretically, we expect all the control variables to have a positive influence on conditions for entrepreneurship. However, it is also important to note that some expected signs may depend on market dynamism and expansion. For instance, foreign aid and private domestic credit may be more sensitive to some dimensions of doing business than others. The intuition for these expected signs is consistent with Tchamyou (2016). In the light of the literature discussed in Section 2, the selected variables are consistent with the inquiry because we have used entrepreneurship, mobile phone and governance variables. The selection of the variables has also been justified by their use in the literature.

The definition of the variables and corresponding sources are provided in Appendix 1, whereas the summary statistics are disclosed in Appendix 2. The correlation matrix which is used to check for potential multicollinearity is provided in Appendix 3. Potential concerns about multicollinearity are exclusively apparent among governance variables. The governance variables are employed in distinct specifications in order to avoid the concerns of multicollinearity. To mitigate the bias associated with the fact that the variables may not be normally distributed, we use an estimation technique other than Ordinary Least Squares.

\section{2. Methodology}

The Generalised Method of Moments (GMM) estimation approach is adopted for the following five reasons. First, the number of countries or cross-sections (N equals 49) is substantially higher than the periodicity per cross-section (T equals 13). Second, the doing of business dependent variables are persistent because correlation coefficients with their respective first lags are higher than the rule of thumb threshold of 0.800 . As shown in 
Appendix 4, the correlation coefficient between the cost of business start-up procedure and its first lag is 0.928 . This is also the case with the number of procedures to enforce a contract (0.997); start-up procedures to register a business (0.940); time required to build a warehouse (0.964); time required to enforce a contract (0.983); time required to register a property (0.918); time required to start a business (0.926); time to export (0.976); time to prepare and pay taxes (0.992) and time to resolve an insolvency (0.999). Third, given that the GMM estimation technique is consistent with a panel data structure, cross-country variations are not eliminated in the estimations. Fourth, the system estimator considers inherent biases in the difference estimator. Fifth, the estimation procedure accounts for endogeneity by controlling for simultaneity in the explanatory variables using an instrumentation process. Moreover, usage of time-invariant omitted variables (or time fixed effects) also helps to mitigate the consequences of endogeneity bias.

In accordance with Bond et al. (2001), the system GMM estimator (see Arellano \& Bover, 1995; Blundell \& Bond, 1998) has better estimation properties than the difference estimator (see Arellano \& Bond, 1991). In this study, we opt for the Roodman (2009a, 2009b) extension of Arellano and Bover (1995) because it has been documented to restrict the proliferation of instruments and control for dependence among cross-sections (see Love \& Zicchino, 2006; Baltagi, 2008; Boateng et al., 2016). Hence, the extended estimation procedure adopts forward orthogonal deviations as opposed to first differences. A two-step procedure is adopted instead of a one-step approach because it addresses concerns of heteroscedasticity given that the one-step procedure only controls for homoscedasticity.

The following equations in level (1) and first difference in (2) summarise the standard system GMM estimation procedure.

$$
\begin{aligned}
B_{i, t}=\sigma_{0}+ & \sigma_{1} B_{i, t-\tau}+\sigma_{2} G_{i, t}+\sigma_{3} M_{i, t}+\sigma_{4} G M_{i, t}+\sum_{h=1}^{5} \delta_{h} W_{h, i, t-\tau}+\eta_{i}+\xi_{t}+\varepsilon_{i, t} \\
B_{i, t}-B_{i, t-\tau}= & \sigma_{1}\left(B_{i, t-\tau}-B_{i, t-2 \tau}\right)+\sigma_{2}\left(G_{i, t}-G_{i, t-\tau}\right)+\sigma_{3}\left(M_{i, t}-M_{i, t-\tau}\right)+\sigma_{4}\left(G M_{i, t}-G M_{i, t-\tau}\right) \\
& +\sum_{h=1}^{5} \delta_{h}\left(W_{h, i, t-\tau}-W_{h, i, t-2 \tau}\right)+\left(\xi_{t}-\xi_{t-\tau}\right)+\varepsilon_{i, t-\tau}
\end{aligned}
$$

where, $B_{i, t}$ is a doing business indicator in country $i$ at period $t, \sigma_{0}$ is a constant, $G$ is governance (political stability, voice and accountability, government effectiveness, regulation quality, corruption-control and rule of law), $M$ represents mobile phone penetration, $G M$ is the interaction between governance and mobile phone penetration, $W$ is the vector of control variables (GDP growth, population growth, foreign direct investment, private domestic credit 
and foreign aid), $\tau$ represents the coefficient of auto-regression, $\xi_{t}$ is the time-specific constant, $\eta_{i}$ is the country-specific effect and $\varepsilon_{i, t}$ the error term.

It is appropriate to devote space to discussing identification properties and exclusion restrictions in the GMM specification. All independent indicators are acknowledged as predetermined or are suspected to be endogenous. Additionally, exclusively time-invariant variables or years are considered to be strictly exogenous (also Boateng et al., 2016; Asongu \& Nwachukwu, 2016b). The intuition for the consideration builds on the fact that it is not likely for the time-invariant variables to become endogenous after a first difference (Roodman, 2009b) ${ }^{5}$.

In the light of above emphasis, the time-invariant variables impact on the outcome variable exclusively through the predetermined variables. Furthermore, the statistical relevance of the exclusion restriction is investigated with the Difference in Hansen Test (DHT) for instrument exogeneity. Accordingly, the null hypothesis of the DHT should not be rejected for the time-invariant indicators to explain the doing business variables exclusively through the suspected endogenous variables. Hence, in the findings that are reported in Section 4, the assumption of exclusion restriction is validated if the alternative hypothesis of the DHT related to instrumental variables (IV) (year, eq(diff)) is not accepted. This is broadly in accordance with the standard IV procedure in which, a rejection of the null hypothesis of the Sargan Overidentifying Restrictions (OIR) test is an indication that the instruments affect the doing business variables beyond the suggested predetermined variable channels (see Beck et al., 2003; Asongu \& Nwachukwu, 2016c).

\section{Empirical Results}

\section{1 Presentation of results}

Tables 1 to 10 respectively present findings corresponding to the: cost of business start-up procedure; procedure to enforce a contract; start-up procedures to register a business; time required to build a warehouse; time required to enforce a contract; time required to register a property; time required to start a business; time to export; time to prepare and pay taxes and time to resolve an insolvency. For all tables: (i) four information criteria are employed to

\footnotetext{
${ }^{5}$ Hence, the procedure for treating ivstyle (years) is 'iv (years, eq(diff))' whereas the gmmstyle is employed for predetermined variables.
} 
assess the validity of the GMM model with forward orthogonal deviations ${ }^{6}$ and (ii) a net effect is computed to assess the modulating effect of mobile phones in the effect of governance on doing business. For instance, in Table 1, in the second column, the net effect from the interaction between mobile phones and political stability is $-8.119([0.110 \times 23.379]$ $+[-10.691])$, where: the mean value of mobile phone penetration is 23.379 , the unconditional effect of political stability is -10.691 while the conditional effect from the interaction between political stability and mobile phones is $0.110^{7}$.

The following findings can be established on the linkages between mobile phone penetration, governance and the doing of business.

First, the net effect of mobile phones in governance is consistently negative on the cost of start-up procedures.

Second, the net effect of mobile phones in governance for the number of procedures to enforce a contract is positive for political stability and negative for the rule of law. For the remaining governance variables, whereas the unconditional effects are insignificant, the corresponding marginal effects are consistently negative. In other words, an additional unit of mobile phone penetration interacts with the governance variables to decrease the number of procedures needed to enforce a contract.

Third, in Table 3, there is a positive net effect on the number of procedures to register a business from the interaction between regulation quality and mobile phones. Furthermore, positive marginal effects are apparent from regressions pertaining to political stability and the rule of law.

Fourth, in spite of positive marginal effects on the time required to build a warehouse, there are negative net effects from interactions with political stability, regulation quality and the rule of law.

Fifth, with regard to the time required to enforce a contract, there is (i) a positive net effect from voice and accountability, despite a corresponding negative marginal effect and (ii) a positive marginal impact from the interaction with government effectiveness.

\footnotetext{
6 "First, the null hypothesis of the second-order Arellano and Bond autocorrelation test (AR (2)) in difference for the absence of autocorrelation in the residuals should not be rejected. Second the Sargan and Hansen over-identification restrictions (OIR) tests should not be significant because their null hypotheses are the positions that instruments are valid or not correlated with the error terms. In essence, while the Sargan OIR test is not robust but not weakened by instruments, the Hansen OIR is robust but weakened by instruments. In order to restrict identification or limit the proliferation of instruments, we have ensured that instruments are lower than the number of cross-sections in most specifications. Third, the Difference in the Hansen Test (DHT) for exogeneity of instruments is also employed to assess the validity of results from the Hansen OIR test. Fourth, a Fischer test for the joint validity of estimated coefficients is also provided" (Asongu \& De Moor, 2017, p.200).

${ }^{7}$ Also see Asongu and Le Roux (2017) for more insights into interactive regressions.
} 
Sixth, in Table 6 on the time required to register a property, (i) with the exception of interactions with government effectiveness, there are negative marginal effects from the interaction of mobile phones with other governance variables and (ii) there are positive net effects from political stability, voice and accountability and the rule of law.

Seventh, both the unconditional and conditional effects are not overwhelmingly significant in Table 7, with the exceptions of positive unconditional and conditional effects from respectively voice and accountability and regulation quality.

Eight, there is a positive (negative) net effect from political stability (regulation quality) with a corresponding negative (positive) marginal effect in Table 8.

Ninth, in Table 9 on the linkages between governance and mobile phone penetration, there is a positive (i) net effect from political stability with a corresponding negative marginal effect and (ii) a marginal effect from the interaction with regulation quality.

Tenth, on the time to resolve insolvency, there are consistently positive marginal effects across specifications and negative net effects from political stability, regulation quality, corruption-control and the rule of law in Table $10^{8}$. Most of the significant control variables have the expected signs.

\section{"Insert Tables 1-10 here"}

\section{2 Further discussion of results and policy implications}

For the most part, our findings have shown that when governance channels are complemented with ICT in the perspective of mobile phone penetration, the outcome on doing business can be positive. This is essentially because when the net effects from the underlying interaction on the cost of and constraints to doing business are not positive, the corresponding marginal impacts are negative. Three practical implications may be deduced from the above. They are: (i) creating favourable economic conditions that enhance mobile phone penetration, (ii) improving governance standards so as to decrease the negative skew of governance variables and (iii) enhancing the environment surrounding the complementarity of mobile phones with governance mechanisms. In what follows, these points are discussed in chronological order.

First, as argued in the introduction, compared to other regions of the world, the penetration potential for mobile phones is highest in Africa. The specific context of SSA is

\footnotetext{
${ }^{8}$ It is important to note that owing to concerns of instrument proliferation and issues in degrees of freedom, four instead of five control variables are used for the specifications in Table 10.
} 
confirmed by Asongu et al. (2016) who maintain that while the usage of mobile phones is lowest in SSA, the corresponding growth rate is highest in the sub-region. Therefore, in order to leverage on such penetration potential for development externalities like business and/or entrepreneurship opportunities, policy reforms should address concerns related to the lack of infrastructure and limited affordability which are important access barriers to mobile phone usage. Universal coverage schemes via non-profit activities and low pricing on the one hand and the liberalisation of the ICT sector and provision of basic mobile phone infrastructure on the other, are steps in the right direction of boosting mobile phone penetration.

Second, most of the governance variables are negatively skewed (see summary statistics) which implies that when governance is already very poor and negatively affects the doing of business, the complementary effect of mobile phone penetration may not lead to the desired results unless improvements in governance standards are undertaken in conjunction with improvements in a favourable environment for the interaction between mobile phones and governance.

Third, our findings for the most part have shown that the mobile phone can be employed as a valuable complementary tool in the role of governance in the doing of business. Therefore, policy actions could improve such complementarity to enhance entrepreneurial activities by involving at least two reform measures. They are (i) tailoring mobile phones to boost openness, transparency and the free flow of data/information between various government institutions and departments and (ii) strengthening mobile-governance applications and services in order to enhance the free flow of information between corporations and government institutions as well as to enable businesses to actively participate in decisions that affect their operations.

In the light of the above, mobile telephony can act as a participative interface between the government and corporations on the one hand and emerging entrepreneurs on the other. For these purposes, policies on mobile phone penetration need to be designed to boost, among others: cost-effectiveness, efficiency, adoption, interaction, outreach and access along the following lines.

First, with regard to 'increasing outreach' due to poor infrastructure networks, it is essential to increase the ownership of mobile phones in remote areas (especially rural regions) that do not have the infrastructure that can accommodate the internet and other communication and transportation facilities. Second, providing entrepreneurs with the means of communicating with the help of mobile phones anywhere and anytime is a step in the right 
direction. Third, the connection between entrepreneurs and government institutions with the help of mobile phones is more effective in certain specific scenarios, compared to more traditional media like posters, radios, brochures and public speeches. Fourth, business activities may be substantially enhanced if mobile phones are designed to be an integral part of the interface between government institutions and entrepreneurs (present and potential). Fifth, communications between entrepreneurs and government institutions can also be enhanced if mobile phone applications are tailored to favour feedbacks and suggestions from entrepreneurs in the doing of business. Sixth, consistent with the narrative in the previous paragraph, affordability of and access to mobile phones can be improved in remote/rural areas by inter alia: subsidising community ownership and mobile infrastructure for collective entrepreneurial projects

Overall, if governance standards are improved and mobile phone penetration levels increased across SSA, the major unemployment concern owing to the growing population in Africa in the post-2015 development agenda can be addressed through private sector activities. We may note that Asongu (2013) has concluded that in the long term, only the private sector can accommodate unemployment resulting from Africa's burgeoning population.

Another policy implication worth discussing is the relevance of ICT in reducing information asymmetry between entrepreneurs and government institutions. Accordingly, the established positive net effects are indications that the mobile phone reduces government inefficiency (which potentially represents an additional cost to doing business) by reducing informational rents, bureaucracy and transaction costs.

In the light of the above, another theoretical implication of the study largely builds on the role of the mobile phone as an information sharing mechanism. This is essentially because information sharing by means of the mobile phone can substantially mitigate information asymmetry between various government departments. Hence, by increasing transparency and reducing informational rents, government institutions can provide more favourable conditions for efficiency in the doing of business. With insights from this clarification, the role of the mobile phone in improving governance for 'doing business' efficiency is broadly consistent with the theoretical basis of efficiency in financial intermediation by means of information sharing offices (such as private credit bureaus and public credit registries) (see Asongu et al., 2017). 


\section{Conclusion and Future Research Directions}

This study has investigated whether mobile phone penetration modulates the effect of different indicators of governance on some indicators of the ease of doing business in SubSaharan Africa with data from the period 2000-2012 by employing the Generalised Method of Moments. Three broad concepts of governance have been used. They are: (i) political (involving voice and accountability and political stability/no violence), (ii) economic (comprising government effectiveness and regulation quality) and (iii) institutional (covering corruption-control and rule of law). Ten dimensions of entrepreneurship were considered. Two main findings were established with respect to the net effects from the interaction between mobile phones and governance dynamics. They comprise: (i) a reduction in the cost of business start-up procedures, the time to build a warehouse and the time to resolve an insolvency and (ii) an increase in the start-up procedure to register a business (though in only one of the six specifications); the time required to enforce a contract; the time required to register a property and the time to prepare and pay taxes. When net effects are adverse, the corresponding marginal impacts are favourable to entrepreneurship for the most part. Implications for policy and theory have been discussed.

The primary contribution of this paper has been to complement the existing macroeconomic and institutional literature on how entrepreneurship can be boosted in less developed countries. The inquiry has combined the issues raised in the introduction by assessing how the potential for mobile phone penetration can improve governance in order to create favourable conditions for entrepreneurship. Such boost in entrepreneurship could potentially address contemporary policy challenges in Africa like inequality, poverty and rising unemployment.

Further research can focus on other instruments through which the mobile phone can be used to enhance entrepreneurship in Africa. Considering mobile phone complementarities like the internet, the degree of innovation and the quality of education are steps in this direction. While there is currently a constraint in the availability of mobile banking data, assessing how the established findings withstand empirical scrutiny with mobile banking data would improve on the extant literature. 


\begin{tabular}{|c|c|c|c|c|c|c|}
\hline & $\begin{array}{l}\text { Political } \\
\text { Stability } \\
\text { (PolS) }\end{array}$ & $\begin{array}{l}\text { Voice \& } \\
\text { Accountability } \\
\text { (VA) }\end{array}$ & $\begin{array}{l}\text { Government } \\
\text { Effectiveness } \\
(\mathrm{GE})\end{array}$ & $\begin{array}{l}\text { Regulation } \\
\text { Quality(RQ) }\end{array}$ & $\begin{array}{l}\text { Corruption- } \\
\text { Control } \\
\text { (CC) }\end{array}$ & $\begin{array}{l}\text { Rule of Law } \\
\text { (RL) }\end{array}$ \\
\hline Constant & $\begin{array}{l}5.421 \\
(0.661)\end{array}$ & $\begin{array}{l}-6.476 \\
(0.511)\end{array}$ & $\begin{array}{l}14.330 * * \\
(0.039)\end{array}$ & $\begin{array}{l}-16.883 \\
(0.174)\end{array}$ & $\begin{array}{l}9.309 \\
(0.274)\end{array}$ & $\begin{array}{l}-5.751 \\
(0.491)\end{array}$ \\
\hline Cost of start-up procedure $(-1)$ & $\begin{array}{l}0.752 * * * \\
(0.000)\end{array}$ & $\begin{array}{l}0.739 * * * \\
(0.000)\end{array}$ & $\begin{array}{l}0.742 * * * \\
(0.000)\end{array}$ & $\begin{array}{l}0.737 * * * \\
(0.000)\end{array}$ & $\begin{array}{l}0.752 * * * \\
(0.000)\end{array}$ & $\begin{array}{l}0.739 * * * \\
(0.000)\end{array}$ \\
\hline Mobile phones (Mob) & $\begin{array}{l}-0.258 * * * \\
(0.000)\end{array}$ & $\begin{array}{l}-0.211 * * * \\
(0.001)\end{array}$ & $\begin{array}{l}-0.259 * * * \\
(0.000)\end{array}$ & $\begin{array}{l}-0.131 * \\
(0.050)\end{array}$ & $\begin{array}{l}-0.348^{* * * *} \\
(0.000)\end{array}$ & $\begin{array}{l}-0.114 * \\
(0.073)\end{array}$ \\
\hline Political Stability & $\begin{array}{l}-10.691 * * * \\
(0.002)\end{array}$ & --- & --- & --- & --- & --- \\
\hline Voice \& Accountability & --- & $\begin{array}{l}-17.184 * * * \\
(0.001)\end{array}$ & --- & --- & --- & --- \\
\hline Government Effectiveness & --- & --- & $\begin{array}{l}-16.040 * * * \\
(0.002)\end{array}$ & --- & --- & --- \\
\hline Regulation Quality & --- & --- & --- & $\begin{array}{l}-22.491 * * * \\
(0.005)\end{array}$ & --- & --- \\
\hline Corruption Control & --- & --- & -- & --- & $\begin{array}{l}-13.257 * * * \\
(0.004)\end{array}$ & --- \\
\hline Rule of Law & --- & --- & --- & --- & --- & $\begin{array}{l}-26.112 * * * \\
(0.000)\end{array}$ \\
\hline 'Political Stability’ $\times$ Mob & $\begin{array}{l}0.110 * * \\
(0.020)\end{array}$ & --- & --- & --- & --- & --- \\
\hline 'Voice \& Accountability' $\times$ Mob & --- & $\begin{array}{l}0.110 * \\
(0.065)\end{array}$ & --- & --- & --- & --- \\
\hline 'Government Effectiveness'×Mob & --- & --- & $\begin{array}{l}0.087 * \\
(0.096)\end{array}$ & --- & --- & --- \\
\hline 'Regulation Quality'×Mob & --- & --- & --- & $\begin{array}{l}0.210 * * * \\
(0.001)\end{array}$ & --- & --- \\
\hline 'Corruption Control' $\times$ Mob & --- & --- & --- & --- & $\begin{array}{l}0.175 * * * \\
(0.004)\end{array}$ & --- \\
\hline 'Rule of Law'×Mob & -- & --- & --- & --- & --- & $\begin{array}{l}0.280 * * * \\
(0.000)\end{array}$ \\
\hline GDP growth & $\begin{array}{l}0.415 * \\
(0.076)\end{array}$ & $\begin{array}{l}0.189 \\
(0.498)\end{array}$ & $\begin{array}{l}0.338 \\
(0.232)\end{array}$ & $\begin{array}{l}0.194 \\
(0.467)\end{array}$ & $\begin{array}{l}0.090 \\
(0.738)\end{array}$ & $\begin{array}{l}0.094 \\
(0.661)\end{array}$ \\
\hline Population growth & $\begin{array}{l}9.822 * * \\
(0.038)\end{array}$ & $\begin{array}{l}13.917 * * * \\
(0.000)\end{array}$ & $\begin{array}{l}6.408 * * \\
(0.018)\end{array}$ & $\begin{array}{l}19.525 * * * \\
(0.000)\end{array}$ & $\begin{array}{l}8.665 * * \\
(0.014)\end{array}$ & $\begin{array}{l}13.735 * * * \\
(0.001)\end{array}$ \\
\hline Foreign Direct Investment & $\begin{array}{l}0.303 * * * \\
(0.000)\end{array}$ & $\begin{array}{l}0.191 * * \\
(0.038)\end{array}$ & $\begin{array}{l}0.013 \\
(0.829)\end{array}$ & $\begin{array}{l}0.272 * * * \\
(0.000)\end{array}$ & $\begin{array}{l}0.332 * * * \\
(0.000)\end{array}$ & $\begin{array}{l}0.193 * * * \\
(0.004)\end{array}$ \\
\hline Foreign Aid & $\begin{array}{l}-1.331 * * * \\
(0.000)\end{array}$ & $\begin{array}{l}-1.433 * * * \\
(0.000)\end{array}$ & $\begin{array}{l}-1.500 * * * \\
(0.000)\end{array}$ & $\begin{array}{l}-1.782 * * * \\
(0.000)\end{array}$ & $\begin{array}{l}-1.596 * * * \\
(0.000)\end{array}$ & $\begin{array}{l}-1.564 * * * \\
(0.000)\end{array}$ \\
\hline Private Domestic Credit & $\begin{array}{l}0.255 \\
(0.126)\end{array}$ & $\begin{array}{l}0.282 \\
(0.173)\end{array}$ & $\begin{array}{l}0.148 \\
(0.339)\end{array}$ & $\begin{array}{l}0.243 \\
(0.289)\end{array}$ & $\begin{array}{l}0.176 \\
(0.271)\end{array}$ & $\begin{array}{l}0.132 \\
(0.375)\end{array}$ \\
\hline Net Effects & -8.119 & -14.612 & -14.006 & -17.581 & -9.165 & -19.565 \\
\hline $\operatorname{AR}(1)$ & $(0.154)$ & $(0.154)$ & $(0.160)$ & $(0.155)$ & $(0.156)$ & $(0.157)$ \\
\hline $\operatorname{AR}(2)$ & $(0.465)$ & $(0.402)$ & $(0.410)$ & $(0.362)$ & $(0.368)$ & $(0.386)$ \\
\hline Sargan OIR & $(0.003)$ & $(0.003)$ & $(0.000)$ & $(0.001)$ & $(0.000)$ & $(0.001)$ \\
\hline Hansen OIR & $(0.581)$ & $(0.456)$ & $(0.216)$ & $(0.494)$ & $(0.410)$ & $(0.615)$ \\
\hline \multicolumn{7}{|l|}{$\begin{array}{l}\text { DHT for instruments } \\
\text { (a)Instruments in levels }\end{array}$} \\
\hline H excluding group & $(0.234)$ & (0.169) & $(0.200)$ & $(0.391)$ & $(0.169)$ & $(0.281)$ \\
\hline $\begin{array}{l}\text { Dif(null, H=exogenous) } \\
\text { (b) IV (years, eq(diff)) }\end{array}$ & $(0.771)$ & $(0.703)$ & $(0.317)$ & $(0.525)$ & $(0.643)$ & $(0.764)$ \\
\hline $\mathrm{H}$ excluding group & $(0.719)$ & $(0.377)$ & $(0.216)$ & $(0.429)$ & $(\mathbf{0 . 4 3 5 )}$ & $(0.518)$ \\
\hline Dif(null, $\mathrm{H}=$ exogenous) & $(0.268)$ & $(0.555)$ & $(0.345)$ & $(\mathbf{0 . 5 3 7})$ & $(\mathbf{0 . 3 6 5 )}$ & $(0.625)$ \\
\hline Fisher & $3991.84 * * *$ & $7194.48 * * *$ & $12591.09 * * *$ & $13910.87 * * *$ & $3775.29 * * *$ & $5831.21 * * *$ \\
\hline Instruments & 42 & 42 & 42 & 42 & 42 & 42 \\
\hline
\end{tabular}




\begin{tabular}{lllllll}
\hline Countries & 45 & 45 & 45 & 45 & 45 & 45 \\
Observations & 312 & 312 & 312 & 312 & 312
\end{tabular}

$*, * *, * * *$ : significance levels of $10 \%, 5 \%$ and 1\% respectively. DHT: Difference in Hansen Test for Exogeneity of Instruments' Subsets. Dif: Difference. OIR: Over-identifying Restrictions Test. The significance of bold values is twofold. 1) The significance of estimated coefficients and the Fisher statistics. 2) The failure to reject the null hypotheses of: a) no autocorrelation in the AR(1) and AR(2) tests and; b) the validity of the instruments in the OIR and DHT tests. na: not applicable because at least one estimated coefficient needed for the computation of net effects is not significant.

Table 2: Governance, mobile phones and procedures to enforce a contract

\begin{tabular}{|c|c|c|c|c|c|c|}
\hline & \multicolumn{6}{|c|}{ Dependent variable: Procedures to enforce a contract } \\
\hline & $\begin{array}{l}\text { Political } \\
\text { Stability } \\
(\text { PolS }) \\
\end{array}$ & $\begin{array}{l}\text { Voice \& } \\
\text { Accountability } \\
\text { (VA) }\end{array}$ & $\begin{array}{l}\text { Government } \\
\text { Effectiveness } \\
\text { (GE) }\end{array}$ & $\begin{array}{l}\text { Regulation } \\
\text { Quality(RQ) }\end{array}$ & $\begin{array}{l}\text { Corruption- } \\
\text { Control } \\
\text { (CC) }\end{array}$ & $\begin{array}{l}\text { Rule of } \\
\text { Law (RL) }\end{array}$ \\
\hline Constant & $\begin{array}{l}-0.508 \\
(0.223)\end{array}$ & $\begin{array}{l}0.270 \\
(0.487)\end{array}$ & $\begin{array}{l}-0.463 * \\
(0.067)\end{array}$ & $\begin{array}{l}-0.292 \\
(0.346)\end{array}$ & $\begin{array}{l}-0.595 * * \\
(0.021)\end{array}$ & $\begin{array}{l}1.177 * * \\
(0.023)\end{array}$ \\
\hline Procedure to enforce a contract $(-1)$ & $\begin{array}{l}1.019 * * * \\
(0.000)\end{array}$ & $\begin{array}{l}0.988 * * * \\
(0.000)\end{array}$ & $\begin{array}{l}1.015 * * * \\
(0.000)\end{array}$ & $\begin{array}{l}1.008 * * * \\
(0.000)\end{array}$ & $\begin{array}{l}1.018 * * * \\
(0.000)\end{array}$ & $\begin{array}{l}0.967 * * * \\
(0.000)\end{array}$ \\
\hline Mobile phones (Mob) & $\begin{array}{l}-0.0006 \\
(0.316)\end{array}$ & $\begin{array}{l}-0.0007 \\
(0.375)\end{array}$ & $\begin{array}{l}-0.0009 * \\
(0.084)\end{array}$ & $\begin{array}{l}-0.0006 \\
(0.195)\end{array}$ & $\begin{array}{l}-0.0005 \\
(0.386)\end{array}$ & $\begin{array}{l}-0.001 * * \\
(0.042)\end{array}$ \\
\hline Political Stability & $\begin{array}{l}0.105^{* * *} \\
(\mathbf{0 . 0 0 7 )}\end{array}$ & --- & --- & --- & --- & --- \\
\hline Voice \& Accountability & --- & $\begin{array}{l}-0.073 \\
(0.149)\end{array}$ & --- & --- & --- & --- \\
\hline Government Effectiveness & --- & -- & $\begin{array}{l}0.057 \\
(0.338)\end{array}$ & --- & --- & --- \\
\hline Regulation Quality & --- & --- & --- & $\begin{array}{l}0.009 \\
(0.902)\end{array}$ & --- & --- \\
\hline Corruption Control & --- & --- & --- & -- & $\begin{array}{l}0.035 \\
(0.388)\end{array}$ & --- \\
\hline Rule of Law & --- & --- & --- & --- & --- & $\begin{array}{l}-\mathbf{0 . 1 5 1} 1^{* *} \\
(\mathbf{0 . 0 3 4 )}\end{array}$ \\
\hline 'Political Stability' $\times$ Mob & $\begin{array}{l}-0.001 * * * \\
(0.000)\end{array}$ & --- & --- & --- & --- & --- \\
\hline 'Voice \& Accountability' $\times$ Mob & -- & $\begin{array}{l}-0.001 * * * \\
(0.009)\end{array}$ & --- & --- & --- & --- \\
\hline 'Government Effectiveness' $\times$ Mob & --- & --- & $\begin{array}{l}-0.002 * * * \\
(0.000)\end{array}$ & --- & --- & --- \\
\hline 'Regulation Quality' $\times$ Mob & --- & --- & --- & $\begin{array}{l}-0.001 * * * \\
(0.000)\end{array}$ & --- & --- \\
\hline 'Corruption Control' $\times$ Mob & --- & --- & --- & --- & $\begin{array}{l}-0.001 * * * \\
(0.000)\end{array}$ & --- \\
\hline 'Rule of Law' $\times$ Mob & --- & --- & --- & --- & --- & $\begin{array}{l}-0.003 \text { **** } \\
(0.000)\end{array}$ \\
\hline GDP growth & $\begin{array}{l}0.002 \\
(0.100)\end{array}$ & $\begin{array}{l}0.001 \\
(0.321)\end{array}$ & $\begin{array}{l}0.002^{*} \\
(0.075)\end{array}$ & $\begin{array}{l}0.001 \\
(0.599)\end{array}$ & $\begin{array}{l}0.003 * * * \\
(0.002)\end{array}$ & $\begin{array}{l}0.001 \\
(0.319)\end{array}$ \\
\hline Population growth & $\begin{array}{l}-0.095 * * * \\
(0.004)\end{array}$ & $\begin{array}{l}-0.021 \\
(0.608)\end{array}$ & $\begin{array}{l}-0.060 * * * \\
(0.003)\end{array}$ & $\begin{array}{l}-0.033 \\
(0.222)\end{array}$ & $\begin{array}{l}-0.066 * * * \\
(0.000)\end{array}$ & $\begin{array}{l}-0.026 \\
(0.323)\end{array}$ \\
\hline Foreign Direct Investment & $\begin{array}{l}-0.002 * * * \\
(0.008)\end{array}$ & $\begin{array}{l}-0.0002 \\
(0.762)\end{array}$ & $\begin{array}{l}-0.0003 \\
(0.708)\end{array}$ & $\begin{array}{l}-0.001 * * \\
(0.039)\end{array}$ & $\begin{array}{l}0.0002 \\
(0.784)\end{array}$ & $\begin{array}{l}-0.002 * \\
(0.073)\end{array}$ \\
\hline Foreign Aid & $\begin{array}{l}0.00002 \\
(0.958)\end{array}$ & $\begin{array}{l}0.0007 \\
(0.154)\end{array}$ & $\begin{array}{l}0.0004 \\
(0.263)\end{array}$ & $\begin{array}{l}0.0003 \\
(0.342)\end{array}$ & $\begin{array}{l}0.00008 \\
(0.803)\end{array}$ & $\begin{array}{l}-0.0003 \\
(0.334)\end{array}$ \\
\hline Private Domestic Credit & $\begin{array}{l}-0.0005 \\
(0.429)\end{array}$ & $\begin{array}{l}0.004 * * \\
(0.048)\end{array}$ & $\begin{array}{l}0.002 * * \\
(0.033)\end{array}$ & $\begin{array}{l}0.002 * * * \\
(0.003)\end{array}$ & $\begin{array}{l}0.002 * * * * \\
(0.001)\end{array}$ & $\begin{array}{l}0.004 * * \\
(0.024)\end{array}$ \\
\hline Net Effects & 0.081 & na & na & na & na & -0.221 \\
\hline $\mathrm{AR}(1)$ & $(0.060)$ & $(0.054)$ & $(0.056)$ & $(0.055)$ & $(0.055)$ & $(0.060)$ \\
\hline $\mathrm{AR}(2)$ & $(0.166)$ & $(0.134)$ & $(0.146)$ & $(0.156)$ & $(\mathbf{0 . 1 3 8})$ & $(0.139)$ \\
\hline Sargan OIR & $(0.581)$ & $(0.063)$ & $(0.926)$ & $(0.943)$ & $(\mathbf{0 . 9 3 3 )}$ & $(0.238)$ \\
\hline Hansen OIR & $(0.863)$ & $(0.684)$ & $(0.729)$ & $(0.871)$ & $(0.490)$ & $(0.631)$ \\
\hline DHT for instruments & & & & & & \\
\hline
\end{tabular}




\begin{tabular}{|c|c|c|c|c|c|c|}
\hline \multicolumn{7}{|l|}{ (a)Instruments in levels } \\
\hline $\mathrm{H}$ excluding group & $(0.382)$ & $(0.443)$ & $(0.743)$ & $(0.559)$ & $(0.707)$ & (0.359) \\
\hline Dif(null, $\mathrm{H}=$ exogenous) & $(0.942)$ & $(0.720)$ & $(0.581)$ & $(0.882)$ & $(0.325)$ & $(0.717)$ \\
\hline \multicolumn{7}{|l|}{ (b) IV (years, eq(diff)) } \\
\hline $\mathrm{H}$ excluding group & $(0.777)$ & (0.943) & $(0.617)$ & $(0.822)$ & $(0.774)$ & (0.919) \\
\hline Dif(null, $\mathrm{H}=$ exogenous) & $(0.748)$ & (0.118) & (0.698) & $(0.683)$ & (0.129) & (0.111) \\
\hline Fisher & $46847.80 * * *$ & $26615.62 * * *$ & $152693.3 * * *$ & $127891.1 * * *$ & $17994.8 * * *$ & $14416.7 * * *$ \\
\hline Instruments & 42 & 42 & 42 & 42 & 42 & 42 \\
\hline Countries & 45 & 45 & 45 & 45 & 45 & 45 \\
\hline Observations & 312 & 312 & 312 & 312 & 312 & 312 \\
\hline
\end{tabular}

***,***: significance levels of 10\%, 5\% and 1\% respectively. DHT: Difference in Hansen Test for Exogeneity of Instruments' Subsets. Dif: Difference. OIR: Over-identifying Restrictions Test. The significance of bold values is twofold. 1) The significance of estimated coefficients and the Fisher statistics. 2) The failure to reject the null hypotheses of: a) no autocorrelation in the AR(1) and AR(2) tests and; b) the validity of the instruments in the OIR and DHT tests. na: not applicable because at least one estimated coefficient needed for the computation of net effects is not significant.

Table 3: Governance, mobile phones and start-up procedures to register a business

\begin{tabular}{|c|c|c|c|c|c|c|}
\hline & \multicolumn{6}{|c|}{ Dependent variable: Start-up procedures to register a business } \\
\hline & $\begin{array}{l}\text { Political } \\
\text { Stability } \\
\text { (PolS) }\end{array}$ & $\begin{array}{l}\text { Voice \& } \\
\text { Accountability } \\
\text { (VA) }\end{array}$ & $\begin{array}{l}\text { Government } \\
\text { Effectiveness } \\
\text { (GE) }\end{array}$ & $\begin{array}{l}\text { Regulation } \\
\text { Quality(RQ) }\end{array}$ & $\begin{array}{l}\text { Corruption- } \\
\text { Control (CC) }\end{array}$ & $\begin{array}{l}\text { Rule of } \\
\text { Law (RL) }\end{array}$ \\
\hline Constant & $\begin{array}{l}-0.468 \\
(0.136)\end{array}$ & $\begin{array}{l}0.047 \\
(0.907)\end{array}$ & $\begin{array}{l}0.808 * * \\
(0.034)\end{array}$ & $\begin{array}{l}0.073 \\
(0.817)\end{array}$ & $\begin{array}{l}0.611 * \\
(0.077)\end{array}$ & $\begin{array}{l}0.282 \\
(0.324)\end{array}$ \\
\hline Procedures to register a business(-1) & $\begin{array}{l}1.011 * * * \\
(0.000)\end{array}$ & $\begin{array}{l}1.018 * * * \\
(0.000)\end{array}$ & $\begin{array}{l}0.982 * * * \\
(0.000)\end{array}$ & $\begin{array}{l}1.012 * * * \\
(0.000)\end{array}$ & $\begin{array}{l}0.996 * * * \\
(0.000)\end{array}$ & $\begin{array}{l}1.016 * * * \\
(0.000)\end{array}$ \\
\hline Mobile phones (Mob) & $\begin{array}{l}0.0004 \\
(0.867)\end{array}$ & $\begin{array}{l}0.0006 \\
(0.758)\end{array}$ & $\begin{array}{l}0.001 \\
(0.366)\end{array}$ & $\begin{array}{l}0.001 \\
(0.502)\end{array}$ & $\begin{array}{l}0.001 \\
(0.376)\end{array}$ & $\begin{array}{l}0.0003 \\
(0.845)\end{array}$ \\
\hline Political Stability & $\begin{array}{l}-0.081 \\
(0.243)\end{array}$ & --- & --- & --- & --- & --- \\
\hline Voice \& Accountability & --- & $\begin{array}{l}0.379 * * * \\
(\mathbf{0 . 0 0 0 )}\end{array}$ & --- & --- & --- & --- \\
\hline Government Effectiveness & --- & --- & $\begin{array}{l}0.194 \\
(0.277)\end{array}$ & --- & --- & --- \\
\hline Regulation Quality & --- & --- & --- & $\begin{array}{l}0.221 * \\
(0.065)\end{array}$ & --- & --- \\
\hline Corruption Control & --- & -- & --- & --- & $\begin{array}{l}0.223 \\
(0.132)\end{array}$ & --- \\
\hline Rule of Law & --- & --- & --- & --- & --- & $\begin{array}{l}-0.009 \\
(0.912)\end{array}$ \\
\hline 'Political Stability' $\times$ Mob & $\begin{array}{l}0.004 * * * \\
(0.007)\end{array}$ & --- & --- & --- & --- & --- \\
\hline 'Voice \& Accountability' $\times$ Mob & --- & $\begin{array}{l}-0.0002 \\
(0.901)\end{array}$ & --- & --- & --- & --- \\
\hline 'Government Effectiveness' $\times$ Mob & --- & -- & $\begin{array}{l}0.002 \\
(0.166)\end{array}$ & --- & --- & --- \\
\hline 'Regulation Quality' $\times$ Mob & --- & --- & --- & $\begin{array}{l}0.005 * * \\
(0.025)\end{array}$ & --- & --- \\
\hline 'Corruption Control' $\times$ Mob & --- & --- & --- & --- & $\begin{array}{l}0.002 \\
(0.196)\end{array}$ & --- \\
\hline 'Rule of Law' $\times$ Mob & --- & --- & --- & --- & --- & $\begin{array}{l}0.006 * * * \\
(0.000)\end{array}$ \\
\hline GDP growth & $\begin{array}{l}0.0008 \\
(0.857)\end{array}$ & $\begin{array}{l}0.001 \\
(0.760)\end{array}$ & $\begin{array}{l}-0.001 \\
(0.706)\end{array}$ & $\begin{array}{l}-0.007 \\
(0.179)\end{array}$ & $\begin{array}{l}0.000004 \\
(0.999)\end{array}$ & $\begin{array}{l}0.0009 \\
(0.824)\end{array}$ \\
\hline Population growth & $\begin{array}{l}-0.005 \\
(0.935)\end{array}$ & $\begin{array}{l}0.001 \\
(0.979)\end{array}$ & $\begin{array}{l}-0.018 \\
(0.778)\end{array}$ & $\begin{array}{l}-0.016 \\
(0.751)\end{array}$ & $\begin{array}{l}0.006 \\
(0.908)\end{array}$ & $\begin{array}{l}-0.051 \\
(0.338)\end{array}$ \\
\hline Foreign Direct Investment & $\begin{array}{l}0.011 * * * \\
(\mathbf{0 . 0 0 0 )}\end{array}$ & $\begin{array}{l}0.006 * * * \\
(0.003)\end{array}$ & $\begin{array}{l}0.008 * * * \\
(0.002)\end{array}$ & $\begin{array}{l}0.010 * * * * \\
(0.002)\end{array}$ & $\begin{array}{l}0.010 * * * \\
(0.000)\end{array}$ & $\begin{array}{l}0.009 * * * \\
(0.000)\end{array}$ \\
\hline Foreign Aid & $\begin{array}{l}-0.012 * * * \\
(0.000)\end{array}$ & $\begin{array}{l}-0.017 * * * \\
(0.000)\end{array}$ & $\begin{array}{l}-0.014 * * * \\
(0.000)\end{array}$ & $\begin{array}{l}-0.014 * * * \\
(0.000)\end{array}$ & $\begin{array}{l}-0.015 * * * \\
(0.000)\end{array}$ & $\begin{array}{l}-0.014 * * * \\
(0.000)\end{array}$ \\
\hline
\end{tabular}




\begin{tabular}{|c|c|c|c|c|c|c|}
\hline Private Domestic Credit & $\begin{array}{l}-0.008 * * * \\
(0.006)\end{array}$ & $\begin{array}{l}-\mathbf{0 . 0 1 7} * * * \\
(0.000)\end{array}$ & $\begin{array}{l}-\mathbf{O . 0 1 8}^{* * * *} \\
(\mathbf{0 . 0 0 0 )}\end{array}$ & $\begin{array}{l}-\mathbf{- 0 . 0 1 9} * * * \\
(0.000)\end{array}$ & $\begin{array}{l}-\mathbf{0 . 0 2 1} 1^{* * * *} \\
(\mathbf{0 . 0 0 0 )}\end{array}$ & $\begin{array}{l}0.039 \\
(0.407)\end{array}$ \\
\hline Net Effects & na & na & na & 0.337 & na & na \\
\hline $\operatorname{AR}(1)$ & $(0.004)$ & $(0.003)$ & $(0.003)$ & $(0.003)$ & $(0.003)$ & $(0.004)$ \\
\hline $\mathrm{AR}(2)$ & $(0.717)$ & $(0.708)$ & $(0.664)$ & $(0.703)$ & $(0.715)$ & $(0.690)$ \\
\hline Sargan OIR & $(0.034)$ & $(0.035)$ & $(0.068)$ & $(0.141)$ & $(0.114)$ & $(0.040)$ \\
\hline Hansen OIR & $(0.142)$ & $(0.348)$ & $(0.668)$ & $(\mathbf{0 . 2 6 0})$ & $(0.340)$ & $(0.240)$ \\
\hline $\begin{array}{l}\text { DHT for instruments } \\
\text { (a)Instruments in levels }\end{array}$ & & & & & & \\
\hline H excluding group & $(0.262)$ & $(0.167)$ & $(0.192)$ & $(\mathbf{0 . 1 3 9})$ & $(0.416)$ & $(\mathbf{0 . 1 3 2})$ \\
\hline $\begin{array}{l}\text { Dif(null, H=exogenous) } \\
\text { (b) IV (years, eq(diff)) }\end{array}$ & $(0.165)$ & $(0.560)$ & $(0.892)$ & $(\mathbf{0 . 4 6 8})$ & $(0.321)$ & $(0.444)$ \\
\hline $\mathrm{H}$ excluding group & $(\mathbf{0 . 1 3 4 )}$ & $(0.340)$ & $(0.727)$ & $(\mathbf{0 . 3 6 8})$ & $(0.405)$ & $(0.159)$ \\
\hline Dif(null, $\mathrm{H}=$ exogenous) & $(0.344)$ & $(0.400)$ & $(\mathbf{0 . 3 8 7})$ & $(\mathbf{0 . 2 0 7})$ & $(0.288)$ & $(0.571)$ \\
\hline Fisher & $9753.58 * * *$ & $1354.60 * * *$ & $2084.74 * * *$ & $5362.74 * * *$ & $1806.21 * * *$ & $751.08 * * *$ \\
\hline Instruments & 42 & 42 & 42 & 42 & 42 & 42 \\
\hline Countries & 45 & 45 & 45 & 45 & 45 & 45 \\
\hline Observations & 312 & 312 & 312 & 312 & 312 & 312 \\
\hline
\end{tabular}

Table 4: Governance, mobile phones and time required to build a warehouse

\begin{tabular}{|c|c|c|c|c|c|c|}
\hline & \multicolumn{6}{|c|}{ Dependent variable: Time required to build a warehouse } \\
\hline & $\begin{array}{l}\text { Political } \\
\text { Stability } \\
\text { (PolS) } \\
\end{array}$ & $\begin{array}{l}\text { Voice \& } \\
\text { Accountability } \\
\text { (VA) }\end{array}$ & $\begin{array}{l}\text { Government } \\
\text { Effectiveness } \\
\text { (GE) } \\
\end{array}$ & $\begin{array}{l}\text { Regulation } \\
\text { Quality(RQ) }\end{array}$ & $\begin{array}{l}\text { Corruption- } \\
\text { Control (CC) }\end{array}$ & $\begin{array}{l}\text { Rule of Law } \\
\text { (RL) }\end{array}$ \\
\hline Constant & $\begin{array}{l}3.403 \\
(0.433)\end{array}$ & $\begin{array}{l}19.388 * * * \\
(0.000)\end{array}$ & $\begin{array}{l}16.660 * * * \\
(0.001)\end{array}$ & $\begin{array}{l}16.374 * * * \\
(0.000)\end{array}$ & $\begin{array}{l}\text { 25.011*** } \\
(0.000)\end{array}$ & $\begin{array}{l}11.944 * * \\
(0.012)\end{array}$ \\
\hline Time to build a warehouse $(-1)$ & $\begin{array}{l}0.992 * * * \\
(0.000)\end{array}$ & $\begin{array}{l}0.927 * * * \\
(0.000)\end{array}$ & $\begin{array}{l}0.946 * * * \\
(0.000)\end{array}$ & $\begin{array}{l}0.909 * * * \\
(0.000)\end{array}$ & $\begin{array}{l}0.920 * * * \\
(0.000)\end{array}$ & $\begin{array}{l}0.944 * * * \\
(0.000)\end{array}$ \\
\hline Mobile phones (Mob) & $\begin{array}{l}-0.036 \\
(0.115)\end{array}$ & $\begin{array}{l}-0.038 \\
(0.295)\end{array}$ & $\begin{array}{l}-0.049 \\
(0.176)\end{array}$ & $\begin{array}{l}0.040 \\
(0.283)\end{array}$ & $\begin{array}{l}-0.055 \\
(0.190)\end{array}$ & $\begin{array}{l}0.008 \\
(0.771)\end{array}$ \\
\hline Political Stability & $\begin{array}{l}-2.645^{* * * *} \\
(0.005)\end{array}$ & --- & --- & --- & --- & --- \\
\hline Voice \& Accountability & --- & $\begin{array}{l}-2.060 \\
(0.132)\end{array}$ & --- & --- & --- & --- \\
\hline Government Effectiveness & --- & --- & $\begin{array}{l}-1.722 \\
(0.316)\end{array}$ & --- & --- & --- \\
\hline Regulation Quality & --- & --- & --- & $\begin{array}{l}-5.610 * \\
(0.054)\end{array}$ & --- & --- \\
\hline Corruption Control & --- & --- & --- & --- & $\begin{array}{l}-0.701 \\
(0.732)\end{array}$ & --- \\
\hline Rule of Law & --- & --- & --- & --- & --- & $\begin{array}{l}-5.458 * * * \\
(0.003)\end{array}$ \\
\hline 'Political Stability’ $\times$ Mob & $\begin{array}{l}0.050 * * \\
(0.011)\end{array}$ & --- & --- & --- & --- & --- \\
\hline 'Voice \& Accountability' ×Mob & --- & $\begin{array}{l}0.009 \\
(0.709)\end{array}$ & --- & --- & --- & --- \\
\hline 'Government Effectiveness' $\times$ Mob & --- & --- & $\begin{array}{l}0.023 \\
(0.383)\end{array}$ & --- & --- & --- \\
\hline 'Regulation Quality’×Mob & --- & --- & --- & $\begin{array}{l}0.094 * * \\
(0.014)\end{array}$ & --- & --- \\
\hline 'Corruption Control' $\times$ Mob & --- & --- & --- & --- & $\begin{array}{l}0.004 \\
(0.876)\end{array}$ & --- \\
\hline
\end{tabular}




\begin{tabular}{|c|c|c|c|c|c|c|}
\hline 'Rule of Law'×Mob & --- & --- & --- & --- & --- & $\begin{array}{l}0.087 * * * \\
(0.001)\end{array}$ \\
\hline GDP growth & $\begin{array}{l}0.128 * * \\
(0.037)\end{array}$ & $\begin{array}{l}0.079 \\
(0.319)\end{array}$ & $\begin{array}{l}0.095 \\
(0.151)\end{array}$ & $\begin{array}{l}0.046 \\
(0.527)\end{array}$ & $\begin{array}{l}-0.055 \\
(0.334)\end{array}$ & $\begin{array}{l}0.089 \\
(0.274)\end{array}$ \\
\hline Population growth & $\begin{array}{l}-0.831 \\
(0.358)\end{array}$ & $\begin{array}{l}-2.305 * * \\
(\mathbf{0 . 0 3 0})\end{array}$ & $\begin{array}{l}-2.253 * * \\
(0.020)\end{array}$ & $\begin{array}{l}-0.366 \\
(0.758)\end{array}$ & $\begin{array}{l}-3.029 * * * \\
(0.004)\end{array}$ & $\begin{array}{l}-1.089 \\
(0.248)\end{array}$ \\
\hline Foreign Direct Investment & $\begin{array}{l}0.235 * * * \\
(\mathbf{0 . 0 0 0 )}\end{array}$ & $\begin{array}{l}0.126 * * * \\
(0.000)\end{array}$ & $\begin{array}{l}0.115 * * * \\
(0.000)\end{array}$ & $\begin{array}{l}0.189 * * * \\
(0.000)\end{array}$ & $\begin{array}{l}0.158 * * * \\
(0.000)\end{array}$ & $\begin{array}{l}0.170 * * * \\
(0.000)\end{array}$ \\
\hline Foreign Aid & $\begin{array}{l}-0.323 * * * \\
(0.000)\end{array}$ & $\begin{array}{l}-0.222 * * * \\
(0.000)\end{array}$ & $\begin{array}{l}-0.232 * * * \\
(0.000)\end{array}$ & $\begin{array}{l}-0.286 * * * \\
(0.000)\end{array}$ & $\begin{array}{l}-0.245 * * * \\
(0.000)\end{array}$ & $\begin{array}{l}-0.284 * * * \\
(0.000)\end{array}$ \\
\hline Private Domestic Credit & $\begin{array}{l}-0.002 \\
(0.959)\end{array}$ & $\begin{array}{l}-0.076 \\
(0.108)\end{array}$ & $\begin{array}{l}2.087 \\
(0.143)\end{array}$ & $\begin{array}{l}-0.057 \\
(0.359)\end{array}$ & $\begin{array}{l}-0.081 \\
(0.137)\end{array}$ & $\begin{array}{l}-0.063 \\
(0.243)\end{array}$ \\
\hline Net Effects & -1.476 & na & na & -3.412 & na & -3.424 \\
\hline $\mathrm{AR}(1)$ & $(0.124)$ & $(0.122)$ & $(\mathbf{0 . 1 2 3})$ & $(0.120)$ & $(0.122)$ & $(0.121)$ \\
\hline $\operatorname{AR}(2)$ & $(\mathbf{0 . 1 5 2})$ & $(0.172)$ & $(\mathbf{0 . 1 6 9 )}$ & $(0.155)$ & $(0.166)$ & $(0.165)$ \\
\hline Sargan OIR & $(\mathbf{0 . 2 3 9})$ & $(0.574)$ & $(\mathbf{0 . 5 6 5})$ & $(0.572)$ & $(0.199)$ & $(0.576)$ \\
\hline Hansen OIR & $(\mathbf{0 . 4 5 0})$ & $(0.979)$ & $(\mathbf{0 . 9 2 7})$ & $(0.792)$ & $(\mathbf{0 . 8 3 8})$ & $(0.960)$ \\
\hline $\begin{array}{l}\text { DHT for instruments } \\
\text { (a)Instruments in levels }\end{array}$ & & & & & & \\
\hline H excluding group & $(\mathbf{0 . 8 1 9 )}$ & $(\mathbf{0 . 3 1 4})$ & $(0.221)$ & $(0.216)$ & $(0.236)$ & $(0.243)$ \\
\hline $\begin{array}{l}\text { Dif(null, H=exogenous) } \\
\text { (b) IV (years, eq(diff)) }\end{array}$ & $(\mathbf{0 . 2 3 4})$ & $(\mathbf{1 . 0 0 0 )}$ & $(\mathbf{0 . 9 9 8 )}$ & $(0.958)$ & $(0.973)$ & (1.000) \\
\hline H excluding group & $(\mathbf{0 . 5 8 8})$ & $(0.918)$ & $(\mathbf{0 . 8 9 2})$ & $(0.748)$ & $(0.746)$ & $(0.886)$ \\
\hline Dif(null, $\mathrm{H=exogenous)}$ & $(\mathbf{0 . 2 0 3})$ & $(0.973)$ & $(\mathbf{0 . 7 1 1 )}$ & $(0.604)$ & $(0.764)$ & $(\mathbf{0 . 9 3 3})$ \\
\hline Fisher & $4368.05 * * *$ & $7643.51 * * *$ & $5318.15 * * *$ & 2133.00*** & $3538.49 * * *$ & $3629.85 * * *$ \\
\hline Instruments & 40 & 40 & 40 & 40 & 40 & 40 \\
\hline Countries & 43 & 43 & 43 & 43 & 43 & 43 \\
\hline Observations & 248 & 248 & 248 & 248 & 248 & 248 \\
\hline
\end{tabular}

***,***: significance levels of $10 \%, 5 \%$ and $1 \%$ respectively. DHT: Difference in Hansen Test for Exogeneity of Instruments' Subsets. Dif: Difference. OIR: Over-identifying Restrictions Test. The significance of bold values is twofold. 1) The significance of estimated coefficients and the Fisher statistics. 2) The failure to reject the null hypotheses of: a) no autocorrelation in the AR(1) and AR(2) tests and; b) the validity of the instruments in the OIR and DHT tests. na: not applicable because at least one estimated coefficient needed for the computation of net effects is not significant.

Table 5: Governance, mobile phones and time required to enforce a contract

\begin{tabular}{|c|c|c|c|c|c|c|}
\hline & \multicolumn{6}{|c|}{ Dependent variable: Time required to enforce a contract } \\
\hline & $\begin{array}{l}\text { Political } \\
\text { Stability } \\
\text { (PolS) }\end{array}$ & $\begin{array}{l}\text { Voice \& } \\
\text { Accountability } \\
\text { (VA) }\end{array}$ & $\begin{array}{l}\text { Government } \\
\text { Effectiveness } \\
\text { (GE) }\end{array}$ & $\begin{array}{l}\text { Regulation } \\
\text { Quality } \\
\text { (RQ) }\end{array}$ & $\begin{array}{l}\text { Corruption- } \\
\text { Control (CC) }\end{array}$ & $\begin{array}{l}\text { Rule of } \\
\text { Law (RL) }\end{array}$ \\
\hline Constant & $\begin{array}{l}26.631 * * * \\
(0.001)\end{array}$ & $\begin{array}{l}\mathbf{2 2 . 3 6 6}^{* * * *} \\
(\mathbf{0 . 0 0 2 )}\end{array}$ & $\begin{array}{l}\text { 27.787** } \\
(\mathbf{0 . 0 1 0})\end{array}$ & $\begin{array}{l}19.902 * * \\
(0.014)\end{array}$ & $\begin{array}{l}15.948 * \\
(0.062)\end{array}$ & $\begin{array}{l}\text { 33.392**** } \\
(\mathbf{0 . 0 0 1 )}\end{array}$ \\
\hline Time to enforce a contract $(-1)$ & $\begin{array}{l}\text { 1.004**** } \\
(0.000)\end{array}$ & $\begin{array}{l}1.010 * * * \\
(0.000)\end{array}$ & $\begin{array}{l}1.042 * * * \\
(0.000)\end{array}$ & $\begin{array}{l}1.027 * * * \\
(0.000)\end{array}$ & $\begin{array}{l}1.041 * * * \\
(0.000)\end{array}$ & $\begin{array}{l}1.011 * * * \\
(0.000)\end{array}$ \\
\hline Mobile phones (Mob) & $\begin{array}{l}-0.061 \\
(0.290)\end{array}$ & $\begin{array}{l}-0.140 * * \\
(0.018)\end{array}$ & $\begin{array}{l}-0.192 * * * \\
(0.009)\end{array}$ & $\begin{array}{l}-0.112 * * \\
(0.016)\end{array}$ & $\begin{array}{l}-0.108 * * \\
(0.033)\end{array}$ & $\begin{array}{l}-0.096 \\
(0.199)\end{array}$ \\
\hline Political Stability & $\begin{array}{l}3.247 * * * \\
(0.001)\end{array}$ & --- & --- & --- & --- & --- \\
\hline Voice \& Accountability & --- & $\begin{array}{l}\text { 6.379** } \\
(0.025)\end{array}$ & --- & --- & --- & --- \\
\hline Government Effectiveness & --- & --- & $\begin{array}{l}-0.107 \\
(0.978)\end{array}$ & --- & --- & --- \\
\hline Regulation Quality & --- & --- & --- & $\begin{array}{l}0.506 \\
(0.874)\end{array}$ & --- & --- \\
\hline Corruption Control & --- & --- & --- & --- & $\begin{array}{l}-0.558 \\
(0.854)\end{array}$ & --- \\
\hline Rule of Law & --- & --- & --- & --- & --- & $\begin{array}{l}-5.420 \\
(0.197)\end{array}$ \\
\hline
\end{tabular}




\begin{tabular}{|c|c|c|c|c|c|c|}
\hline 'Political Stability' $\times$ Mob & $\begin{array}{l}-0.022 \\
(0.279)\end{array}$ & --- & --- & --- & --- & --- \\
\hline 'Voice \& Accountability' $\times$ Mob & --- & $\begin{array}{l}-0.098 * * \\
(0.042)\end{array}$ & --- & --- & --- & --- \\
\hline 'Government Effectiveness' $\times$ Mob & --- & --- & $\begin{array}{l}0.142 * * \\
(0.018)\end{array}$ & --- & --- & --- \\
\hline 'Regulation Quality'×Mob & --- & --- & --- & $\begin{array}{l}0.033 \\
(0.613)\end{array}$ & --- & --- \\
\hline 'Corruption Control' $\times$ Mob & --- & --- & --- & --- & $\begin{array}{l}0.013 \\
(0.679)\end{array}$ & --- \\
\hline 'Rule of Law'×Mob & --- & --- & --- & --- & --- & $\begin{array}{l}-0.011 \\
(0.793)\end{array}$ \\
\hline GDP growth & $\begin{array}{l}0.728 * * \\
(0.012)\end{array}$ & $\begin{array}{l}0.591 * * \\
(0.022)\end{array}$ & $\begin{array}{l}1.135 * * * \\
(0.000)\end{array}$ & $\begin{array}{l}0.887 * * * \\
(0.001)\end{array}$ & $\begin{array}{l}\mathbf{0 . 7 3 3} * * * \\
(\mathbf{0 . 0 0 4 )}\end{array}$ & $\begin{array}{l}0.786 * * * \\
(\mathbf{0 . 0 0 1 )}\end{array}$ \\
\hline Population growth & $\begin{array}{l}-7.884 * * * \\
(0.000)\end{array}$ & $\begin{array}{l}-10.502 * * * \\
(0.000)\end{array}$ & $\begin{array}{l}-13.004 * * * \\
(0.000)\end{array}$ & $\begin{array}{l}-10.140 * * * \\
(0.000)\end{array}$ & $\begin{array}{l}-11.395 * * * \\
(0.000)\end{array}$ & $\begin{array}{l}-14.841 * * * \\
(0.000)\end{array}$ \\
\hline Foreign Direct Investment & $\begin{array}{l}-0.047 \\
(0.393)\end{array}$ & $\begin{array}{l}-0.052 \\
(0.326)\end{array}$ & $\begin{array}{l}-0.238 * * * \\
(0.000)\end{array}$ & $\begin{array}{l}-0.202 * * * \\
(0.002)\end{array}$ & $\begin{array}{l}-0.224 * * * \\
(0.000)\end{array}$ & $\begin{array}{l}-0.042 \\
(0.420)\end{array}$ \\
\hline Foreign Aid & $\begin{array}{l}0.032 \\
(0.494)\end{array}$ & $\begin{array}{l}0.012 \\
(0.731)\end{array}$ & $\begin{array}{l}-0.006 \\
(0.886)\end{array}$ & $\begin{array}{l}-0.003 \\
(0.917)\end{array}$ & $\begin{array}{l}0.022 \\
(0.560)\end{array}$ & $\begin{array}{l}0.105^{* *} \\
(0.010)\end{array}$ \\
\hline Private Domestic Credit & $\begin{array}{l}-0.423 * * * \\
(0.000)\end{array}$ & $\begin{array}{l}-0.310 * * * \\
(0.002)\end{array}$ & $\begin{array}{l}-0.470 * * \\
(0.020)\end{array}$ & $\begin{array}{l}-0.370 * * \\
(0.033)\end{array}$ & $\begin{array}{l}-0.483 * * * \\
(0.001)\end{array}$ & $\begin{array}{l}-0.354 * * * \\
(0.008)\end{array}$ \\
\hline Net Effects & na & 4.087 & na & na & na & na \\
\hline $\operatorname{AR}(1)$ & $(0.028)$ & $(0.029)$ & $(0.027)$ & $(0.029)$ & $(0.027)$ & $(0.027)$ \\
\hline $\operatorname{AR}(2)$ & $(0.859)$ & $(0.693)$ & $(0.954)$ & $(0.915)$ & $(0.934)$ & $(0.670)$ \\
\hline Sargan OIR & $(0.445)$ & $(0.306)$ & $(0.510)$ & $(0.627)$ & $(0.331)$ & $(0.410)$ \\
\hline Hansen OIR & $(0.832)$ & $(0.937)$ & $(0.303)$ & $(0.768)$ & $(0.383)$ & $(0.719)$ \\
\hline $\begin{array}{l}\text { DHT for instruments } \\
\text { (a)Instruments in levels }\end{array}$ & & & & & & \\
\hline $\mathrm{H}$ excluding group & $(0.765)$ & $(0.685)$ & $(0.484)$ & $(0.631)$ & $(0.592)$ & $(0.488)$ \\
\hline $\begin{array}{l}\text { Dif(null, H=exogenous) } \\
\text { (b) IV (years, eq(diff)) }\end{array}$ & $(0.716)$ & $(0.922)$ & $(0.244)$ & $(0.706)$ & $(0.276)$ & $(0.733)$ \\
\hline $\mathrm{H}$ excluding group & $(0.747)$ & $(0.736)$ & $(0.429)$ & $(0.724)$ & $(0.415)$ & $(0.562)$ \\
\hline Dif(null, $\mathrm{H}=$ exogenous) & $(0.720)$ & $(0.988)$ & $(0.206)$ & $(0.598)$ & $(0.347)$ & $(0.772)$ \\
\hline Fisher & $217058.87 * * *$ & $10678.92 * * *$ & $8469.18 * * *$ & $12375.8 * * *$ & $14951.12 * * *$ & $9959.80 * * *$ \\
\hline Instruments & 42 & 42 & 42 & 42 & 42 & 42 \\
\hline Countries & 45 & 45 & 45 & 45 & 45 & 45 \\
\hline Observations & 312 & 312 & 312 & 312 & 312 & 312 \\
\hline
\end{tabular}

*,**,***: significance levels of $10 \%, 5 \%$ and $1 \%$ respectively. DHT: Difference in Hansen Test for Exogeneity of Instruments' Subsets. Dif: Difference. OIR: Over-identifying Restrictions Test. The significance of bold values is twofold. 1) The significance of estimated coefficients and the Fisher statistics. 2) The failure to reject the null hypotheses of: a) no autocorrelation in the AR(1) and AR(2) tests and; b) the validity of the instruments in the OIR and DHT tests. na: not applicable because at least one estimated coefficient needed for the computation of net effects is not significant. 


\begin{tabular}{|c|c|c|c|c|c|c|}
\hline & \multicolumn{6}{|c|}{ Dependent variable: Time required to register a property } \\
\hline & $\begin{array}{l}\text { Political } \\
\text { Stability } \\
(\text { PolS }) \\
\end{array}$ & $\begin{array}{l}\text { Voice \& } \\
\text { Accountability } \\
\text { (VA) }\end{array}$ & $\begin{array}{l}\text { Government } \\
\text { Effectiveness } \\
\text { (GE) }\end{array}$ & $\begin{array}{l}\text { Regulation } \\
\text { Quality(RQ) }\end{array}$ & $\begin{array}{l}\text { Corruption- } \\
\text { Control } \\
\text { (CC) } \\
\end{array}$ & $\begin{array}{l}\text { Rule of Law } \\
\text { (RL) }\end{array}$ \\
\hline Constant & $\begin{array}{l}22.652 * * \\
(0.010)\end{array}$ & $\begin{array}{l}26.822 * * * * \\
(0.001)\end{array}$ & $\begin{array}{l}12.041 \\
(0.136)\end{array}$ & $\begin{array}{l}24.546 * * * * \\
(0.006)\end{array}$ & $\begin{array}{l}5.422 \\
(0.263)\end{array}$ & $\begin{array}{l}22.382 * * \\
(\mathbf{0 . 0 3 0})\end{array}$ \\
\hline Time to register a property $(-1)$ & $\begin{array}{l}0.783 * * * \\
(\mathbf{0 . 0 0 0 )}\end{array}$ & $\begin{array}{l}0.760 * * * \\
(0.000)\end{array}$ & $\begin{array}{l}0.767 * * * \\
(\mathbf{0 . 0 0 0 )}\end{array}$ & $\begin{array}{l}0.762^{* * * *} \\
(0.000)\end{array}$ & $\begin{array}{l}0.823 * * * \\
(0.000)\end{array}$ & $\begin{array}{l}0.801 * * * \\
(0.000)\end{array}$ \\
\hline Mobile phones (Mob) & $\begin{array}{l}-0.041 \\
(0.452)\end{array}$ & $\begin{array}{l}-0.119 * * * \\
(\mathbf{0 . 0 0 1})\end{array}$ & $\begin{array}{l}-0.011 \\
(0.865)\end{array}$ & $\begin{array}{l}-0.072 \\
(0.348)\end{array}$ & $\begin{array}{l}0.021 \\
(0.712)\end{array}$ & $\begin{array}{l}-0.079 \\
(0.218)\end{array}$ \\
\hline Political Stability & $\begin{array}{l}4.502 * * \\
(0.038)\end{array}$ & --- & --- & --- & --- & --- \\
\hline Voice \& Accountability & --- & $\begin{array}{l}7.156 * * * \\
(0.007)\end{array}$ & --- & --- & --- & --- \\
\hline Government Effectiveness & --- & --- & $\begin{array}{l}-3.097 \\
(0.379)\end{array}$ & --- & --- & --- \\
\hline Regulation Quality & --- & --- & --- & $\begin{array}{l}-4.583 \\
(0.279)\end{array}$ & --- & --- \\
\hline Corruption Control & --- & --- & --- & --- & $\begin{array}{l}4.322 \\
(0.113)\end{array}$ & --- \\
\hline Rule of Law & --- & --- & --- & --- & --- & $\begin{array}{l}\text { 7.336*** } \\
(0.011)\end{array}$ \\
\hline 'Political Stability’ $\times$ Mob & $\begin{array}{l}-0.096 * * * \\
(0.007)\end{array}$ & --- & --- & --- & --- & --- \\
\hline 'Voice \& Accountability' $\times$ Mob & --- & $\begin{array}{l}-0.153 * * * \\
(0.000)\end{array}$ & --- & --- & --- & --- \\
\hline 'Government Effectiveness' $\times$ Mob & --- & --- & $\begin{array}{l}-0.075 \\
(0.117)\end{array}$ & --- & --- & --- \\
\hline 'Regulation Quality' $\times$ Mob & --- & --- & --- & $\begin{array}{l}-0.133 * * \\
(\mathbf{0 . 0 3 9})\end{array}$ & --- & --- \\
\hline 'Corruption Control' $\times$ Mob & --- & --- & --- & --- & $\begin{array}{l}-0.113 \text { *** } \\
(\mathbf{0 . 0 2 5})\end{array}$ & --- \\
\hline 'Rule of Law'×Mob & --- & --- & --- & --- & --- & $\begin{array}{l}-0.191 * * * \\
(0.000)\end{array}$ \\
\hline GDP growth & $\begin{array}{l}0.682 * * * \\
(0.009)\end{array}$ & $\begin{array}{l}0.673 * * \\
(0.036)\end{array}$ & $\begin{array}{l}0.834 * * * \\
(0.000)\end{array}$ & $\begin{array}{l}0.694 * * * \\
(0.000)\end{array}$ & $\begin{array}{l}0.926 * * * \\
(0.000)\end{array}$ & $\begin{array}{l}0.745^{* * * *} \\
(0.006)\end{array}$ \\
\hline Population growth & $\begin{array}{l}-2.950 \\
(0.145)\end{array}$ & $\begin{array}{l}-2.737 \\
(0.218)\end{array}$ & $\begin{array}{l}-1.287 \\
(0.493)\end{array}$ & $\begin{array}{l}-4.799 * * \\
(0.026)\end{array}$ & $\begin{array}{l}1.022 \\
(0.284)\end{array}$ & $\begin{array}{l}-3.364 \\
(0.158)\end{array}$ \\
\hline Foreign Direct Investment & $\begin{array}{l}-0.224 * * * \\
(0.009)\end{array}$ & $\begin{array}{l}-0.333 * * * \\
(0.005)\end{array}$ & $\begin{array}{l}-0.165^{* *} \\
(0.036)\end{array}$ & $\begin{array}{l}-0.206 * \\
(0.057)\end{array}$ & $\begin{array}{l}-0.163 * \\
(0.072)\end{array}$ & $\begin{array}{l}-0.233 * * \\
(0.021)\end{array}$ \\
\hline Foreign Aid & $\begin{array}{l}0.042 * \\
(0.087)\end{array}$ & $\begin{array}{l}0.020 \\
(0.537)\end{array}$ & $\begin{array}{l}-0.014 \\
(0.732)\end{array}$ & $\begin{array}{l}0.016 \\
(0.660)\end{array}$ & $\begin{array}{l}-0.022 \\
(0.556)\end{array}$ & $\begin{array}{l}0.090 * * \\
(0.029)\end{array}$ \\
\hline Private Domestic Credit & $\begin{array}{l}-0.072 \\
(0.246)\end{array}$ & $\begin{array}{l}-0.048 \\
(0.539)\end{array}$ & $\begin{array}{l}-0.048 \\
(0.481)\end{array}$ & $\begin{array}{l}0.098 \\
(0.316)\end{array}$ & $\begin{array}{l}-0.109 \\
(0.245)\end{array}$ & $\begin{array}{l}-0.093 \\
(0.147)\end{array}$ \\
\hline Net Effects & 2.257 & 3.579 & na & na & na & 2.870 \\
\hline $\mathrm{AR}(1)$ & $(0.079)$ & $(0.082)$ & $(0.076)$ & $(0.075)$ & $(0.076)$ & $(0.077)$ \\
\hline $\mathrm{AR}(2)$ & $(0.325)$ & $(0.327)$ & $(\mathbf{0 . 3 2 3})$ & $(\mathbf{0 . 3 3 2})$ & $(\mathbf{0 . 3 3 3})$ & $(0.321)$ \\
\hline Sargan OIR & $(0.927)$ & $(0.974)$ & $(\mathbf{0 . 8 8 3})$ & $(0.595)$ & $(\mathbf{0 . 7 3 7})$ & $(0.939)$ \\
\hline Hansen OIR & $(0.827)$ & $(0.884)$ & $(0.936)$ & $(0.571)$ & $(\mathbf{0 . 7 8 5})$ & $(0.726)$ \\
\hline $\begin{array}{l}\text { DHT for instruments } \\
\text { (a)Instruments in levels }\end{array}$ & & & & & & \\
\hline $\mathrm{H}$ excluding group & $(0.852)$ & $(0.710)$ & $(0.762)$ & $(0.266)$ & $(0.981)$ & $(0.946)$ \\
\hline Dif(null, $\mathrm{H}=$ exogenous) & $(0.647)$ & $(0.829)$ & $(0.892)$ & $(0.727)$ & $(\mathbf{0 . 4 3 8})$ & $(0.415)$ \\
\hline (b) IV (years, eq(diff)) & & & & & & \\
\hline H excluding group & $(\mathbf{0 . 7 5 4 )}$ & $(0.760)$ & $(0.920)$ & $(0.790)$ & $(0.936)$ & $(0.762)$ \\
\hline Dif(null, $\mathrm{H}=$ exogenous) & $(0.696)$ & $(0.864)$ & $(0.659)$ & $(0.161)$ & $(0.196)$ & $(0.421)$ \\
\hline Fisher & $44329.73 * * *$ & $3157.16 * * *$ & $1340.01 * * *$ & $4019.59 * * *$ & $2504.42 * * *$ & $3414.33 * * *$ \\
\hline
\end{tabular}




\begin{tabular}{|c|c|c|c|c|c|c|}
\hline Instruments & 41 & 41 & 41 & 41 & 41 & 41 \\
\hline Countries & 45 & 45 & 45 & 45 & 45 & 45 \\
\hline Observations & 282 & 282 & 282 & 282 & 282 & 282 \\
\hline
\end{tabular}

*,**,***: significance levels of 10\%, 5\% and 1\% respectively. DHT: Difference in Hansen Test for Exogeneity of Instruments' Subsets. Dif: Difference. OIR: Over-identifying Restrictions Test. The significance of bold values is twofold. 1) The significance of estimated coefficients and the Fisher statistics. 2) The failure to reject the null hypotheses of: a) no autocorrelation in the AR(1) and AR(2) tests and; b) the validity of the instruments in the OIR and DHT tests. na: not applicable because at least one estimated coefficient needed for the computation of net effects is not significant.

Table 7: Governance, mobile phones and time required to start a business

\begin{tabular}{|c|c|c|c|c|c|c|}
\hline & \multicolumn{6}{|c|}{ Dependent variable: Time required to start a business } \\
\hline & $\begin{array}{l}\text { Political } \\
\text { Stability } \\
(\text { PolS })\end{array}$ & $\begin{array}{l}\text { Voice \& } \\
\text { Accountability } \\
\text { (VA) }\end{array}$ & $\begin{array}{l}\text { Government } \\
\text { Effectiveness } \\
\text { (GE) }\end{array}$ & $\begin{array}{l}\text { Regulation } \\
\text { Quality(RQ) }\end{array}$ & $\begin{array}{l}\text { Corruption- } \\
\text { Control (CC) }\end{array}$ & $\begin{array}{l}\text { Rule of } \\
\text { Law (RL) }\end{array}$ \\
\hline Constant & $\begin{array}{l}-11.281 * \\
(0.080)\end{array}$ & $\begin{array}{l}-5.836 \\
(0.463)\end{array}$ & $\begin{array}{l}-10.292 * * \\
(0.045)\end{array}$ & $\begin{array}{l}10.747 \\
(0.140)\end{array}$ & $\begin{array}{l}-9.704 * * \\
(0.032)\end{array}$ & $\begin{array}{l}-17.780 * * * \\
(0.002)\end{array}$ \\
\hline Time required to start a business $(-1)$ & $\begin{array}{l}1.203 * * * \\
(0.000)\end{array}$ & $\begin{array}{l}1.224 * * * \\
(0.000)\end{array}$ & $\begin{array}{l}1.193 * * * \\
(0.000)\end{array}$ & $\begin{array}{l}1.264 * * * \\
(0.000)\end{array}$ & $\begin{array}{l}1.122 * * * \\
(0.000)\end{array}$ & $\begin{array}{l}1.227 * * * \\
(0.000)\end{array}$ \\
\hline Mobile phones (Mob) & $\begin{array}{l}-0.050 \\
(0.263)\end{array}$ & $\begin{array}{l}-0.080 \\
(0.151)\end{array}$ & $\begin{array}{l}0.031 \\
(0.573)\end{array}$ & $\begin{array}{l}-0.031 \\
(0.504)\end{array}$ & $\begin{array}{l}0.013 \\
(0.754)\end{array}$ & $\begin{array}{l}0.023 \\
(0.685)\end{array}$ \\
\hline Political Stability & $\begin{array}{l}-0.598 \\
(0.703)\end{array}$ & --- & --- & --- & --- & -- \\
\hline Voice \& Accountability & --- & $\begin{array}{l}5.791 * * \\
(0.017)\end{array}$ & --- & --- & --- & --- \\
\hline Government Effectiveness & --- & --- & $\begin{array}{l}2.483 \\
(0.359)\end{array}$ & --- & --- & --- \\
\hline Regulation Quality & --- & --- & --- & $\begin{array}{l}4.033 \\
(0.306)\end{array}$ & --- & --- \\
\hline Corruption Control & --- & --- & --- & --- & $\begin{array}{l}1.967 \\
(0.490)\end{array}$ & --- \\
\hline Rule of Law & --- & --- & --- & --- & --- & $\begin{array}{l}0.796 \\
(0.767)\end{array}$ \\
\hline 'Political Stability’ $\times$ Mob & $\begin{array}{l}-0.009 \\
(0.792)\end{array}$ & --- & --- & --- & --- & --- \\
\hline 'Voice \& Accountability' ×Mob & --- & $\begin{array}{l}0.040 \\
(0.458)\end{array}$ & --- & --- & --- & --- \\
\hline 'Government Effectiveness’ $\times$ Mob & --- & -- & $\begin{array}{l}0.099 \\
(0.185)\end{array}$ & --- & --- & --- \\
\hline 'Regulation Quality'×Mob & --- & --- & --- & $\begin{array}{l}0.243 * * * \\
(0.000)\end{array}$ & --- & --- \\
\hline 'Corruption Control' $\times$ Mob & --- & --- & --- & --- & $\begin{array}{l}0.034 \\
(0.437)\end{array}$ & --- \\
\hline 'Rule of Law' $\times$ Mob & --- & --- & --- & --- & -- & $\begin{array}{l}0.088 \\
(0.240)\end{array}$ \\
\hline GDP growth & $\begin{array}{l}0.187 * * \\
(0.010)\end{array}$ & $\begin{array}{l}0.163 * * * \\
(0.002)\end{array}$ & $\begin{array}{l}0.117 \\
(0.200)\end{array}$ & $\begin{array}{l}0.070 \\
(0.431)\end{array}$ & $\begin{array}{l}0.189 * * * \\
(\mathbf{0 . 0 0 4 )}\end{array}$ & $\begin{array}{l}0.200 * * * \\
(0.007)\end{array}$ \\
\hline Population growth & $\begin{array}{l}-1.383 \\
(0.472)\end{array}$ & $\begin{array}{l}-1.322 \\
(0.516 a ̀ ~\end{array}$ & $\begin{array}{l}1.586 \\
(0.354)\end{array}$ & $\begin{array}{l}-3.620^{*} \\
(0.054)\end{array}$ & $\begin{array}{l}1.965 \\
(0.164)\end{array}$ & $\begin{array}{l}0.470 \\
(0.810)\end{array}$ \\
\hline Foreign Direct Investment & $\begin{array}{l}0.169 * * * \\
(0.000)\end{array}$ & $\begin{array}{l}0.102 * * \\
(0.013)\end{array}$ & $\begin{array}{l}0.258 * * * \\
(0.000)\end{array}$ & $\begin{array}{l}0.246 * * * \\
(0.000)\end{array}$ & $\begin{array}{l}0.116 * * \\
(0.018)\end{array}$ & $\begin{array}{l}0.217 * * * \\
(0.001)\end{array}$ \\
\hline Foreign Aid & $\begin{array}{l}0.033 \\
(0.263)\end{array}$ & $\begin{array}{l}-0.086 * * \\
(0.021)\end{array}$ & $\begin{array}{l}-0.012 \\
(0.735)\end{array}$ & $\begin{array}{l}0.015 \\
(0.654)\end{array}$ & $\begin{array}{l}0.038 \\
(0.241)\end{array}$ & $\begin{array}{l}0.025 \\
(0.516)\end{array}$ \\
\hline Private Domestic Credit & $\begin{array}{l}-0.175^{* *} \\
(0.040)\end{array}$ & $\begin{array}{l}-0.281^{*} \\
(0.060)\end{array}$ & $\begin{array}{l}-0.134 \\
(0.258)\end{array}$ & $\begin{array}{l}-0.341 * * \\
(0.027)\end{array}$ & $\begin{array}{l}-0.131 \\
(0.191)\end{array}$ & $\begin{array}{l}-0.137 \\
(0.262)\end{array}$ \\
\hline Net Effects & na & na & na & na & na & na \\
\hline
\end{tabular}




\begin{tabular}{|c|c|c|c|c|c|c|}
\hline $\operatorname{AR}(1)$ & $(0.042)$ & $(0.034)$ & $(0.039)$ & $(0.033)$ & $(0.042)$ & $(0.038)$ \\
\hline $\operatorname{AR}(2)$ & $(0.824)$ & $(0.822)$ & $(0.861)$ & $(0.850)$ & $(0.788)$ & $(0.826)$ \\
\hline Sargan OIR & $(0.007)$ & $(0.004)$ & $(0.019)$ & $(0.009)$ & $(0.001)$ & $(0.014)$ \\
\hline Hansen OIR & $(0.849)$ & $(0.513)$ & $(0.641)$ & $(0.754)$ & $(0.831)$ & $(0.698)$ \\
\hline \multicolumn{7}{|l|}{$\begin{array}{l}\text { DHT for instruments } \\
\text { (a)Instruments in levels }\end{array}$} \\
\hline $\mathrm{H}$ excluding group & $(0.264)$ & $(\mathbf{0 . 2 2 3})$ & $(0.283)$ & $(0.215)$ & $(0.166)$ & $(0.303)$ \\
\hline $\begin{array}{l}\text { Dif(null, H=exogenous) } \\
\text { (b) IV (years, eq(diff)) }\end{array}$ & $(0.970)$ & $(0.704)$ & $(0.791)$ & $(0.937)$ & $(0.988)$ & $(\mathbf{0 . 8 3 4})$ \\
\hline $\mathrm{H}$ excluding group & $(0.941)$ & $(0.842)$ & $(0.589)$ & $(0.870)$ & $(0.806)$ & $(0.863)$ \\
\hline Dif(null, $\mathrm{H}=$ =xogenous) & $(\mathbf{0 . 3 2 2})$ & $(\mathbf{0 . 1 0 0 )}$ & $(0.556)$ & $(\mathbf{0 . 3 0 5})$ & $(0.599)$ & $(\mathbf{0 . 2 3 8})$ \\
\hline Fisher & $838.09 * * *$ & $884.08 * * *$ & $2008.87 * * *$ & $1446.52 * * *$ & $1011.74 * * *$ & 731.88**** \\
\hline Instruments & 42 & 42 & 42 & 42 & 42 & 42 \\
\hline Countries & 45 & 45 & 45 & 45 & 45 & 45 \\
\hline Observations & 312 & 312 & 312 & 312 & 312 & 312 \\
\hline
\end{tabular}

*,**,***: significance levels of $10 \%, 5 \%$ and $1 \%$ respectively. DHT: Difference in Hansen Test for Exogeneity of Instruments' Subsets. Dif: Difference. OIR: Over-identifying Restrictions Test. The significance of bold values is twofold. 1) The significance of estimated coefficients and the Fisher statistics. 2) The failure to reject the null hypotheses of: a) no autocorrelation in the AR(1) and AR(2) tests and; b) the validity of the instruments in the OIR and DHT tests. na: not applicable because at least one estimated coefficient needed for the computation of net effects is not significant.

Table 8: Governance, mobile phones and time to export

\begin{tabular}{|c|c|c|c|c|c|c|}
\hline & \multicolumn{6}{|c|}{ Dependent variable: Time to export } \\
\hline & $\begin{array}{l}\text { Political } \\
\text { Stability } \\
\text { (PolS) }\end{array}$ & $\begin{array}{l}\text { Voice \& } \\
\text { Accountability } \\
\text { (VA) }\end{array}$ & $\begin{array}{l}\text { Government } \\
\text { Effectiveness } \\
\text { (GE) }\end{array}$ & $\begin{array}{l}\text { Regulation } \\
\text { Quality(RQ) }\end{array}$ & $\begin{array}{l}\text { Corruption- } \\
\text { Control (CC) }\end{array}$ & $\begin{array}{l}\text { Rule of Law } \\
\text { (RL) }\end{array}$ \\
\hline Constant & $\begin{array}{l}-1.435 \\
(0.135)\end{array}$ & $\begin{array}{l}-1.586 * \\
(0.079)\end{array}$ & $\begin{array}{l}-2.236 * * * \\
(0.002)\end{array}$ & $\begin{array}{l}-4.802 * * * * \\
(0.000)\end{array}$ & $\begin{array}{l}-1.045 \\
(0.141)\end{array}$ & $\begin{array}{l}-0.704 \\
(0.393)\end{array}$ \\
\hline Time to export (-1) & $\begin{array}{l}1.004 * * * \\
(0.000)\end{array}$ & $\begin{array}{l}1.002 * * * \\
(0.000)\end{array}$ & $\begin{array}{l}0.994 * * * \\
(0.000)\end{array}$ & $\begin{array}{l}0.997 * * * \\
(0.000)\end{array}$ & $\begin{array}{l}1.002 * * * \\
(0.000)\end{array}$ & $\begin{array}{l}1.024 * * * \\
(0.000)\end{array}$ \\
\hline Mobile phones (Mob) & $\begin{array}{l}0.007 \\
(0.126)\end{array}$ & $\begin{array}{l}0.008 \\
(0.121)\end{array}$ & $\begin{array}{l}0.014 * * * \\
(0.007)\end{array}$ & $\begin{array}{l}\mathbf{0 . 0 3 5} * * * \\
(\mathbf{0 . 0 0 0 )}\end{array}$ & $\begin{array}{l}0.005 \\
(0.245)\end{array}$ & $\begin{array}{l}0.002 \\
(0.628)\end{array}$ \\
\hline Political Stability & $\begin{array}{l}1.135 * * * \\
(0.000)\end{array}$ & --- & --- & -- & -- & --- \\
\hline Voice \& Accountability & --- & $\begin{array}{l}-0.366 \\
(0.199)\end{array}$ & --- & --- & --- & --- \\
\hline Government Effectiveness & --- & --- & $\begin{array}{l}-0.723 * \\
(0.078)\end{array}$ & --- & --- & --- \\
\hline Regulation Quality & --- & --- & --- & $\begin{array}{l}-2.337 * * * \\
(0.002)\end{array}$ & --- & --- \\
\hline Corruption Control & --- & --- & --- & --- & $\begin{array}{l}-0.324 \\
(0.400)\end{array}$ & --- \\
\hline Rule of Law & --- & --- & --- & --- & --- & $\begin{array}{l}0.022 \\
(0.957)\end{array}$ \\
\hline 'Political Stability’ $\times$ Mob & $\begin{array}{l}-0.013 * * * \\
(0.004)\end{array}$ & --- & --- & --- & --- & --- \\
\hline 'Voice \& Accountability' $\times$ Mob & -- & $\begin{array}{l}0.002 \\
(0.576)\end{array}$ & --- & --- & --- & --- \\
\hline 'Government Effectiveness'×Mob & --- & --- & $\begin{array}{l}0.003 \\
(0.495)\end{array}$ & --- & --- & --- \\
\hline 'Regulation Quality'×Mob & --- & --- & --- & $\begin{array}{l}0.022 * * \\
(0.018)\end{array}$ & --- & --- \\
\hline 'Corruption Control' $\times$ Mob & --- & --- & --- & --- & $\begin{array}{l}0.0003 \\
(0.922)\end{array}$ & --- \\
\hline 'Rule of Law' $\times$ Mob & --- & --- & --- & --- & --- & $\begin{array}{l}-0.002 \\
(0.504\end{array}$ \\
\hline GDP growth & $\begin{array}{l}-0.049 * * * \\
(0.001)\end{array}$ & $\begin{array}{l}-0.053 * * * \\
(0.001)\end{array}$ & $\begin{array}{l}-0.046 * * * \\
(0.000)\end{array}$ & $\begin{array}{l}-0.056 * * * \\
(0.003)\end{array}$ & $\begin{array}{l}-0.055 * * * \\
(0.000)\end{array}$ & $\begin{array}{l}-0.048 * * * \\
(0.000)\end{array}$ \\
\hline
\end{tabular}




\begin{tabular}{|c|c|c|c|c|c|c|}
\hline Population growth & $\begin{array}{l}0.067 \\
(0.825)\end{array}$ & $\begin{array}{l}-0.060 \\
(0.802)\end{array}$ & $\begin{array}{l}0.146 \\
(0.448)\end{array}$ & $\begin{array}{l}0.591 * * \\
(0.023)\end{array}$ & $\begin{array}{l}-0.304 \\
(0.186)\end{array}$ & $\begin{array}{l}-0.616 * * * \\
(0.002)\end{array}$ \\
\hline Foreign Direct Investment & $\begin{array}{l}-\mathbf{0 . 0 3 0} * * * \\
(\mathbf{0 . 0 0 0 )}\end{array}$ & $\begin{array}{l}-0.018 * * * \\
(0.000)\end{array}$ & $\begin{array}{l}-0.024 * * * \\
(0.000)\end{array}$ & $\begin{array}{l}-0.012 * * \\
(0.011)\end{array}$ & $\begin{array}{l}-0.021 * * * \\
(0.000)\end{array}$ & $\begin{array}{l}-0.016 * * * \\
(0.000)\end{array}$ \\
\hline Foreign Aid & $\begin{array}{l}\mathbf{0 . 0 3 3} * * * \\
(\mathbf{0 . 0 0 0 )}\end{array}$ & $\begin{array}{l}0.025 * * * \\
(0.000)\end{array}$ & $\begin{array}{l}0.022 * * * \\
(0.000)\end{array}$ & $\begin{array}{l}\mathbf{0 . 0 1 3} * * * \\
(0.000)\end{array}$ & $\begin{array}{l}\mathbf{0 . 0 2 9} * * * \\
(0.000)\end{array}$ & $\begin{array}{l}\mathbf{0 . 0 2 8} * * * \\
(0.000)\end{array}$ \\
\hline Private Domestic Credit & $\begin{array}{l}-0.010 \\
(0.233)\end{array}$ & $\begin{array}{l}0.0003 \\
(0.973)\end{array}$ & $\begin{array}{l}0.004 \\
(0.463)\end{array}$ & $\begin{array}{l}0.016 * * \\
(0.012)\end{array}$ & $\begin{array}{l}-0.001 \\
(0.870)\end{array}$ & $\begin{array}{l}-0.003 \\
(0.725)\end{array}$ \\
\hline Net Effects & 0.831 & na & na & -1.822 & na & na \\
\hline $\operatorname{AR}(1)$ & $(0.021)$ & $(0.026)$ & $(0.026)$ & $(0.024)$ & $(0.023)$ & $(0.024)$ \\
\hline $\operatorname{AR}(2)$ & $(0.684)$ & $(\mathbf{0 . 6 2 8 )}$ & $(0.599)$ & $(0.597)$ & $(0.642)$ & $(0.611)$ \\
\hline Sargan OIR & $(0.932)$ & $(0.843)$ & $(0.682)$ & $(0.187)$ & $(0.776)$ & $(0.748)$ \\
\hline Hansen OIR & (0.337) & $(0.406)$ & $(0.290)$ & $(0.382)$ & (0.298) & (0.332) \\
\hline $\begin{array}{l}\text { DHT for instruments } \\
\text { (a)Instruments in levels }\end{array}$ & & & & & & \\
\hline H excluding group & $(\mathbf{0 . 5 5 3 )}$ & $(0.511)$ & $(0.477)$ & $(0.492)$ & $(0.851)$ & $(\mathbf{0 . 3 3 8})$ \\
\hline $\begin{array}{l}\text { Dif(null, H=exogenous) } \\
\text { (b) IV (years, eq(diff)) }\end{array}$ & $(0.248)$ & $(0.341)$ & $(\mathbf{0 . 2 3 4})$ & $(0.324)$ & (0.115) & $(0.362)$ \\
\hline H excluding group & $(0.500)$ & $(0.278)$ & (0.178) & $(0.316)$ & $(0.366)$ & $(0.200)$ \\
\hline Dif(null, $\mathrm{H}=$ exogenous) & $(0.154)$ & $(\mathbf{0 . 7 3 1 )}$ & (0.738) & $(0.546)$ & $(0.245)$ & $(\mathbf{0 . 7 8 3 )}$ \\
\hline Fisher & $6172.95 * * *$ & $4858.44 * * *$ & $3994.85 * * *$ & $7273.29 * * *$ & $7356.54 * * *$ & $3979.05 * * *$ \\
\hline Instruments & 40 & 40 & 40 & 40 & 40 & 40 \\
\hline Countries & 43 & 43 & 43 & 43 & 43 & 43 \\
\hline Observations & 248 & 248 & 248 & 248 & 248 & 248 \\
\hline
\end{tabular}

$*, * *, * *$ : significance levels of $10 \%, 5 \%$ and 1\% respectively. DHT: Difference in Hansen Test for Exogeneity of Instruments' Subsets. Dif: Difference. OIR: Over-identifying Restrictions Test. The significance of bold values is twofold. 1) The significance of estimated coefficients and the Fisher statistics. 2) The failure to reject the null hypotheses of: a) no autocorrelation in the AR(1) and AR(2) tests and; b) the validity of the instruments in the OIR and DHT tests. na: not applicable because at least one estimated coefficient needed for the computation of net effects is not significant.

Table 9: Governance, mobile phones and time to prepare and pay taxes

\begin{tabular}{|c|c|c|c|c|c|c|}
\hline & \multicolumn{6}{|c|}{ Dependent variable: Time to prepare and pay taxes } \\
\hline & $\begin{array}{l}\text { Political } \\
\text { Stability } \\
\text { (PolS) }\end{array}$ & $\begin{array}{l}\text { Voice \& } \\
\text { Accountability } \\
\text { (VA) }\end{array}$ & $\begin{array}{l}\text { Government } \\
\text { Effectiveness } \\
\text { (GE) }\end{array}$ & $\begin{array}{l}\text { Regulation } \\
\text { Quality(RQ) }\end{array}$ & $\begin{array}{l}\text { Corruption- } \\
\text { Control (CC) }\end{array}$ & $\begin{array}{l}\text { Rule of Law } \\
\text { (RL) }\end{array}$ \\
\hline Constant & $\begin{array}{l}\text { 24.808*** } \\
(0.001)\end{array}$ & $\begin{array}{l}18.955 * * * \\
(0.004)\end{array}$ & $\begin{array}{l}11.470 \\
(0.196)\end{array}$ & $\begin{array}{l}19.336 * * \\
(0.020)\end{array}$ & $\begin{array}{l}12.461 * \\
(0.098)\end{array}$ & $\begin{array}{l}22.569 * * \\
(0.023)\end{array}$ \\
\hline Time to prepare and pay taxes $(-1)$ & $\begin{array}{l}0.997 * * * \\
(0.000)\end{array}$ & $\begin{array}{l}0.959 * * * \\
(0.000)\end{array}$ & $\begin{array}{l}0.962 * * * \\
(0.000)\end{array}$ & $\begin{array}{l}0.972 * * * \\
(0.000)\end{array}$ & $\begin{array}{l}0.925 * * * \\
(0.000)\end{array}$ & $\begin{array}{l}0.951 * * * \\
(0.000)\end{array}$ \\
\hline Mobile phones (Mob) & $\begin{array}{l}0.038 \\
(0.380)\end{array}$ & $\begin{array}{l}0.099 * * \\
(0.029)\end{array}$ & $\begin{array}{l}0.147 * * \\
(0.011)\end{array}$ & $\begin{array}{l}0.105 * * \\
(0.036)\end{array}$ & $\begin{array}{l}0.246 * * * \\
(0.000)\end{array}$ & $\begin{array}{l}0.142 * * * \\
(0.008)\end{array}$ \\
\hline Political Stability & $\begin{array}{l}5.476 * * \\
(0.038)\end{array}$ & --- & --- & --- & --- & --- \\
\hline Voice \& Accountability & --- & $\begin{array}{l}-4.368 \\
(0.199)\end{array}$ & --- & --- & --- & --- \\
\hline Government Effectiveness & --- & --- & $\begin{array}{l}-8.662 * \\
(0.058)\end{array}$ & --- & --- & --- \\
\hline Regulation Quality & --- & --- & --- & $\begin{array}{l}-7.113 \\
(0.119)\end{array}$ & --- & --- \\
\hline Corruption Control & --- & --- & --- & --- & $\begin{array}{l}-16.062 * * * \\
(0.000)\end{array}$ & --- \\
\hline Rule of Law & --- & --- & --- & --- & --- & $\begin{array}{l}-6.261 \\
(0.163)\end{array}$ \\
\hline 'Political Stability' $\times$ Mob & $\begin{array}{l}-0.057 * * \\
(0.040)\end{array}$ & --- & --- & --- & --- & --- \\
\hline 'Voice \& Accountability' $\times$ Mob & --- & $\begin{array}{l}0.031 \\
(0.386)\end{array}$ & --- & --- & --- & --- \\
\hline
\end{tabular}




\begin{tabular}{|c|c|c|c|c|c|c|}
\hline 'Government Effectiveness' $\times$ Mob & $\begin{array}{ll}-- \\
-1\end{array}$ & $\begin{array}{ll}-- \\
\end{array}$ & $\begin{array}{l}0.057 \\
(0.104)\end{array}$ & $\begin{array}{ll}-- \\
-1\end{array}$ & $\begin{array}{ll}-- \\
\end{array}$ & $\begin{array}{ll}-- \\
-1\end{array}$ \\
\hline 'Regulation Quality’ $\times$ Mob & --- & --- & --- & $\begin{array}{l}0.124 * * * \\
(0.008)\end{array}$ & --- & --- \\
\hline 'Corruption Control' $\times$ Mob & --- & --- & --- & --- & $\begin{array}{l}0.042 \\
(0.155)\end{array}$ & --- \\
\hline 'Rule of Law' $\times$ Mob & --- & --- & --- & --- & --- & $\begin{array}{l}0.004 \\
(0.898)\end{array}$ \\
\hline GDP growth & $\begin{array}{l}-0.447 * * * \\
(0.004)\end{array}$ & $\begin{array}{l}-0.243 * \\
(0.059)\end{array}$ & $\begin{array}{l}-0.202 \\
(0.133)\end{array}$ & $\begin{array}{l}-0.186 \\
(0.163)\end{array}$ & $\begin{array}{l}-0.268 * * \\
(0.026)\end{array}$ & $\begin{array}{l}-0.387 * * * \\
(0.007)\end{array}$ \\
\hline Population growth & $\begin{array}{l}-4.554 * * \\
(0.011)\end{array}$ & $\begin{array}{l}-2.145 \\
(0.121)\end{array}$ & $\begin{array}{l}-1.043 \\
(0.628)\end{array}$ & $\begin{array}{l}-3.578 * \\
(0.092)\end{array}$ & $\begin{array}{l}-0.593 \\
(0.701)\end{array}$ & $\begin{array}{l}-3.376 \\
(0.138)\end{array}$ \\
\hline Foreign Direct Investment & $\begin{array}{l}-0.175 * * * \\
(0.000)\end{array}$ & $\begin{array}{l}-0.153 * * * \\
(0.003)\end{array}$ & $\begin{array}{l}-0.132 * * * \\
(0.001)\end{array}$ & $\begin{array}{l}-0.115 * * \\
(0.049)\end{array}$ & $\begin{array}{l}-0.258 * * * \\
(0.001)\end{array}$ & $\begin{array}{l}-0.216 * * * \\
(0.001)\end{array}$ \\
\hline Foreign Aid & $\begin{array}{l}0.095 * * * \\
(0.000)\end{array}$ & $\begin{array}{l}-0.017 \\
(0.315)\end{array}$ & $\begin{array}{l}-0.045 \\
(0.175)\end{array}$ & $\begin{array}{l}-0.025 \\
(0.272)\end{array}$ & $\begin{array}{l}-0.161 * * * \\
(0.005)\end{array}$ & $\begin{array}{l}-0.046 * \\
(0.077)\end{array}$ \\
\hline Private Domestic Credit & $\begin{array}{l}-\mathbf{0 . 3 8 9} * * * \\
(0.000)\end{array}$ & $\begin{array}{l}-0.220 * * * \\
(0.007)\end{array}$ & $\begin{array}{l}-0.196 * \\
(0.078)\end{array}$ & $\begin{array}{l}-0.362 * * * \\
(0.000)\end{array}$ & $\begin{array}{l}-\mathbf{0 . 1 8 6} * * * \\
(0.002)\end{array}$ & $\begin{array}{l}-0.264 * * \\
(0.012)\end{array}$ \\
\hline Net Effects & 4.143 & na & na & na & na & na \\
\hline $\operatorname{AR}(1)$ & $(0.057)$ & $(0.051)$ & $(0.052)$ & $(0.052)$ & $(0.045)$ & $(0.051)$ \\
\hline $\operatorname{AR}(2)$ & $(0.239)$ & $(0.185)$ & $(0.181)$ & $(0.192)$ & $(0.191)$ & (0.198) \\
\hline Sargan OIR & (0.919) & $(\mathbf{0 . 9 2 3 )}$ & $(\mathbf{0 . 9 3 4 )}$ & $(\mathbf{0 . 8 8 5})$ & $(\mathbf{0 . 7 5 3 )}$ & $(0.829)$ \\
\hline Hansen OIR & (0.198) & $(\mathbf{0 . 8 3 8})$ & $(\mathbf{0 . 8 2 0})$ & $(0.627)$ & $(0.828)$ & $(\mathbf{0 . 8 2 3 )}$ \\
\hline $\begin{array}{l}\text { DHT for instruments } \\
\text { (a)Instruments in levels }\end{array}$ & & & & & & \\
\hline H excluding group & $(0.813)$ & $(0.527)$ & $(0.845)$ & $(0.432)$ & $(0.599)$ & $(0.871)$ \\
\hline $\begin{array}{l}\text { Dif(null, H=exogenous) } \\
\text { (b) IV (years, eq(diff)) }\end{array}$ & $(0.070)$ & $(0.856)$ & $(0.641)$ & $(0.658)$ & $(0.806)$ & $(0.624)$ \\
\hline H excluding group & $(0.282)$ & $(0.710)$ & $(0.860)$ & $(0.690)$ & $(0.801)$ & $(0.630)$ \\
\hline Dif(null, $\mathrm{H}=$ exogenous) & $(0.181)$ & $(0.851)$ & $(0.402)$ & $(0.335)$ & $(0.583)$ & $(0.955)$ \\
\hline Fisher & $22126.09 * * *$ & $22232.50 * * *$ & $8664.48 * * *$ & $283816.1 * * *$ & $9800.48 * * *$ & $19413.02 * * *$ \\
\hline Instruments & 40 & 40 & 40 & 40 & 40 & 40 \\
\hline Countries & 43 & 43 & 43 & 43 & 43 & 43 \\
\hline Observations & 248 & 248 & 248 & 248 & 248 & 248 \\
\hline
\end{tabular}

*,**,***: significance levels of 10\%, 5\% and 1\% respectively. DHT: Difference in Hansen Test for Exogeneity of Instruments' Subsets. Dif: Difference. OIR: Over-identifying Restrictions Test. The significance of bold values is twofold. 1) The significance of estimated coefficients and the Fisher statistics. 2) The failure to reject the null hypotheses of: a) no autocorrelation in the AR(1) and AR(2) tests and; b) the validity of the instruments in the OIR and DHT tests. na: not applicable because at least one estimated coefficient needed for the computation of net effects is not significant.

Table 10: Governance, mobile phones and time to resolve insolvency

\begin{tabular}{|c|c|c|c|c|c|c|}
\hline & \multicolumn{6}{|c|}{ Dependent variable: Time to resolve insolvency } \\
\hline & $\begin{array}{l}\text { Political } \\
\text { Stability } \\
\text { (PolS) }\end{array}$ & $\begin{array}{l}\text { Voice \& } \\
\text { Accountability } \\
\text { (VA) }\end{array}$ & $\begin{array}{l}\text { Government } \\
\text { Effectiveness } \\
\text { (GE) }\end{array}$ & $\begin{array}{l}\text { Regulation } \\
\text { Quality(RQ) }\end{array}$ & $\begin{array}{l}\text { Corruption- } \\
\text { Control (CC) }\end{array}$ & $\begin{array}{l}\text { Rule of Law } \\
\text { (RL) }\end{array}$ \\
\hline Constant & $\begin{array}{l}-0.017 * * * \\
(0.000)\end{array}$ & $\begin{array}{l}-\mathbf{0 . 0 3 8} * * * \\
(0.000)\end{array}$ & $\begin{array}{l}-0.091 * * * \\
(0.000)\end{array}$ & $\begin{array}{l}-0.065 * * * \\
(0.000)\end{array}$ & $\begin{array}{l}-0.062 * * * \\
(0.001)\end{array}$ & $\begin{array}{l}-0.069 * * * \\
(0.000)\end{array}$ \\
\hline Time to resolve insolvency $(-1)$ & $\begin{array}{l}1.003 * * * \\
(0.000)\end{array}$ & $\begin{array}{l}1.011 * * * \\
(0.000)\end{array}$ & $\begin{array}{l}1.024 * * * \\
(0.000)\end{array}$ & $\begin{array}{l}1.015 * * * \\
(0.000)\end{array}$ & $\begin{array}{l}1.017 * * * \\
(\mathbf{0 . 0 0 0 )}\end{array}$ & $\begin{array}{l}1.016 * * * \\
(0.000)\end{array}$ \\
\hline Mobile phones (Mob) & $\begin{array}{l}0.00009^{* * * *} \\
(0.000)\end{array}$ & $\begin{array}{l}\text { 0.0001*** } \\
(\mathbf{0 . 0 0 0 )}\end{array}$ & $\begin{array}{l}0.0003 * * * \\
(0.000)\end{array}$ & $\begin{array}{l}0.0002 * * * \\
(0.000)\end{array}$ & $\begin{array}{l}0.0001 * * * \\
(0.001)\end{array}$ & $\begin{array}{l}0.0002 * * * \\
(0.000)\end{array}$ \\
\hline Political Stability & $\begin{array}{l}-0.003 * * * \\
(0.000)\end{array}$ & --- & --- & --- & --- & --- \\
\hline Voice \& Accountability & --- & $\begin{array}{l}-0.002 \\
(0.336)\end{array}$ & --- & --- & --- & --- \\
\hline Government Effectiveness & --- & --- & $\begin{array}{l}-0.005 \\
(0.133)\end{array}$ & --- & --- & --- \\
\hline
\end{tabular}




\begin{tabular}{|c|c|c|c|c|c|c|}
\hline Regulation Quality & --- & --- & --- & $\begin{array}{l}-0.006 * * \\
(0.027)\end{array}$ & --- & --- \\
\hline Corruption Control & --- & --- & --- & --- & $\begin{array}{l}-0.009 * * \\
(0.042)\end{array}$ & --- \\
\hline Rule of Law & --- & --- & --- & --- & --- & $\begin{array}{l}-0.004 * \\
(0.073)\end{array}$ \\
\hline 'Political Stability' $\times$ Mob & $\begin{array}{l}0.00004 * * * \\
(0.000)\end{array}$ & --- & --- & --- & --- & --- \\
\hline 'Voice \& Accountability' ×Mob & --- & $\begin{array}{l}\text { 0.00003* } \\
(\mathbf{0 . 0 8 7 )}\end{array}$ & --- & --- & --- & --- \\
\hline 'Government Effectiveness' $\times$ Mob & --- & --- & $\begin{array}{l}0.0001 * * * \\
(0.000)\end{array}$ & --- & --- & --- \\
\hline 'Regulation Quality'×Mob & --- & --- & --- & $\begin{array}{l}\mathbf{0 . 0 0 0 1} * * * \\
(0.000)\end{array}$ & --- & --- \\
\hline 'Corruption Control' $\times$ Mob & --- & --- & --- & --- & $\begin{array}{l}0.0001 * * * \\
(0.000)\end{array}$ & --- \\
\hline 'Rule of Law' $\times$ Mob & --- & --- & --- & --- & --- & $\begin{array}{l}0.0001 * * * \\
(0.000)\end{array}$ \\
\hline GDP growth & $\begin{array}{l}-0.0002 * * \\
(0.022)\end{array}$ & $\begin{array}{l}-0.0001 \\
(0.135)\end{array}$ & $\begin{array}{l}-0.0001 * \\
(0.066)\end{array}$ & $\begin{array}{l}-0.0002 * * * \\
(0.007)\end{array}$ & $\begin{array}{l}-0.0002 * * \\
(0.025)\end{array}$ & $\begin{array}{l}-0.0002 * \\
(0.054)\end{array}$ \\
\hline Population growth & $\begin{array}{l}0.001 * * * \\
(0.004)\end{array}$ & $\begin{array}{l}0.001 \\
(0.112)\end{array}$ & $\begin{array}{l}0.001 \\
(0.144)\end{array}$ & $\begin{array}{l}0.002 * * * \\
(0.001)\end{array}$ & $\begin{array}{l}0.001 \\
(0.176)\end{array}$ & $\begin{array}{l}0.002 * * \\
(0.013)\end{array}$ \\
\hline Foreign Direct Investment & $\begin{array}{l}0.00006 * * \\
(0.037)\end{array}$ & $\begin{array}{l}0.00002 \\
(0.478)\end{array}$ & $\begin{array}{l}-0.00002 \\
(0.746)\end{array}$ & $\begin{array}{l}-0.0001 \\
(0.119)\end{array}$ & $\begin{array}{l}-0.00001 \\
(0.801)\end{array}$ & $\begin{array}{l}0.00004 \\
(0.174)\end{array}$ \\
\hline Foreign Aid & $\begin{array}{l}0.00001 \\
(0.689)\end{array}$ & $\begin{array}{l}-0.000009 \\
(0.636)\end{array}$ & $\begin{array}{l}-0.00002 \\
(0.437)\end{array}$ & $\begin{array}{l}0.00005 \\
(0.199)\end{array}$ & $\begin{array}{l}-0.00001 \\
(0.310)\end{array}$ & $\begin{array}{l}-0.00002 * * \\
(0.034)\end{array}$ \\
\hline Net Effects & -0.002 & na & na & -0.003 & -0.006 & -0.001 \\
\hline $\operatorname{AR}(1)$ & $(0.314)$ & $(0.316)$ & $(0.316)$ & $(0.315)$ & $(0.316)$ & $(0.314)$ \\
\hline $\operatorname{AR}(2)$ & $(0.996)$ & $(0.560)$ & $(0.655)$ & $(0.763)$ & $(0.961)$ & $(0.525)$ \\
\hline Sargan OIR & $(0.941)$ & $(0.638)$ & $(0.822)$ & $(0.704)$ & $(0.416)$ & $(0.777)$ \\
\hline Hansen OIR & $(0.699)$ & $(0.931)$ & $(0.741)$ & $(0.757)$ & $(0.772)$ & $(0.510)$ \\
\hline $\begin{array}{l}\text { DHT for instruments } \\
\text { (a)Instruments in levels }\end{array}$ & & & & & & \\
\hline $\mathrm{H}$ excluding group & $(0.986)$ & $(0.991)$ & $(0.948)$ & $(0.967)$ & $(0.681)$ & $(0.960)$ \\
\hline $\begin{array}{l}\text { Dif(null, H=exogenous) } \\
\text { (b) IV (years, eq(diff)) }\end{array}$ & $(\mathbf{0 . 3 3 6})$ & $(0.688)$ & $(0.438)$ & $(0.433)$ & $(0.678)$ & $(0.205)$ \\
\hline $\mathrm{H}$ excluding group & $(0.982)$ & $(0.968)$ & $(0.965)$ & $(0.566)$ & $(0.933)$ & $(0.749)$ \\
\hline Dif(null, $\mathrm{H}=$ exogenous) & $(0.092)$ & $(0.484)$ & $(0.154)$ & $(0.819)$ & $(0.248)$ & $(0.181)$ \\
\hline Fisher & $3.85 \mathrm{e}+06 * * *$ & $3.45 \mathrm{e}+06 * * *$ & $9.72 \mathrm{e}+06^{* * * *}$ & $8.21 \mathrm{e}+06$ & $849695.9 * * *$ & $2.22 \mathrm{e}+06^{* * * *}$ \\
\hline Instruments & 38 & 38 & 38 & 38 & 38 & 38 \\
\hline Countries & 38 & 38 & 38 & 38 & 38 & 38 \\
\hline Observations & 284 & 284 & 284 & 284 & 284 & 284 \\
\hline
\end{tabular}

***,***: significance levels of $10 \%, 5 \%$ and $1 \%$ respectively. DHT: Difference in Hansen Test for Exogeneity of Instruments' Subsets. Dif: Difference. OIR: Over-identifying Restrictions Test. The significance of bold values is twofold. 1) The significance of estimated coefficients and the Fisher statistics. 2) The failure to reject the null hypotheses of: a) no autocorrelation in the AR(1) and AR(2) tests and; b) the validity of the instruments in the OIR and DHT tests. na: not applicable because at least one estimated coefficient needed for the computation of net effects is not significant. 


\section{Appendices}

\section{Appendix 1: Definitions of variables}

\begin{tabular}{|c|c|c|c|}
\hline Variables & Signs & Definitions of variables (Measurement) & Sources \\
\hline $\begin{array}{l}\text { Cost of starting } \\
\text { business }\end{array}$ & Costostart & $\begin{array}{l}\text { Cost of business start-up procedures ( } \% \text { of GNI per } \\
\text { capita) }\end{array}$ & $\begin{array}{l}\text { World Bank } \\
\text { (WDI) }\end{array}$ \\
\hline $\begin{array}{l}\text { Contract } \\
\text { enforcement }\end{array}$ & Contractenf & Procedures to enforce a contract (number) & $\begin{array}{l}\text { World Bank } \\
\text { (WDI) }\end{array}$ \\
\hline $\begin{array}{l}\text { Start-up } \\
\text { procedure }\end{array}$ & Startupproced & Start-up procedures to register a business (number) & $\begin{array}{l}\text { World Bank } \\
\text { (WDI) }\end{array}$ \\
\hline Ware house time & Timewarehouse & Time required to build a warehouse (days) & $\begin{array}{l}\text { World Bank } \\
\text { (WDI) }\end{array}$ \\
\hline $\begin{array}{l}\text { Time to enforce a } \\
\text { contract }\end{array}$ & Timenforcontr & $\begin{array}{l}\text { Timenforcontr: Time required to enforce a contract } \\
\text { (days) }\end{array}$ & $\begin{array}{l}\text { World Bank } \\
\text { (WDI) }\end{array}$ \\
\hline $\begin{array}{l}\text { Time to register a } \\
\text { property }\end{array}$ & Timeregprop & Time required to register a property (days) & $\begin{array}{l}\text { World Bank } \\
\text { (WDI) }\end{array}$ \\
\hline $\begin{array}{l}\text { Time to start a } \\
\text { business }\end{array}$ & Timestartbus & Time required to start a business (days) & $\begin{array}{l}\text { World Bank } \\
\text { (WDI) }\end{array}$ \\
\hline Time to export & Timexport & Time to export (days) & $\begin{array}{l}\text { World Bank } \\
\text { (WDI) }\end{array}$ \\
\hline $\begin{array}{l}\text { Time to pay } \\
\text { taxes }\end{array}$ & Timetaxes & Time to prepare and pay taxes (hours) & $\begin{array}{l}\text { World Bank } \\
\text { (WDI) }\end{array}$ \\
\hline $\begin{array}{l}\text { Resolving an } \\
\text { insolvency }\end{array}$ & Timeresinsolv & Time to resolve insolvency (years) & $\begin{array}{c}\text { World Bank } \\
\text { (WDI) }\end{array}$ \\
\hline Political Stability & Pols & $\begin{array}{l}\text { "Political stability/no violence (estimate): measured as } \\
\text { the perceptions of the likelihood that the government } \\
\text { will be destabilized or overthrown by unconstitutional } \\
\text { and violent means, including domestic violence and } \\
\text { terrorism". }\end{array}$ & $\begin{array}{c}\text { World Bank } \\
\text { (WDI) }\end{array}$ \\
\hline $\begin{array}{l}\text { Voice \& } \\
\text { Accountability }\end{array}$ & VA & $\begin{array}{l}\text { "Voice and accountability (estimate): measures the } \\
\text { extent to which a country's citizens are able to } \\
\text { participate in selecting their government and to enjoy } \\
\text { freedom of expression, freedom of association and a free } \\
\text { media" }\end{array}$ & $\begin{array}{c}\text { World Bank } \\
\text { (WDI) }\end{array}$ \\
\hline $\begin{array}{l}\text { Government } \\
\text { Effectiveness }\end{array}$ & GE & $\begin{array}{l}\text { "Government effectiveness (estimate): measures the } \\
\text { quality of public services, the quality and degree of } \\
\text { independence from political pressures of the civil } \\
\text { service, the quality of policy formulation and } \\
\text { implementation, and the credibility of governments' } \\
\text { commitments to such policies". }\end{array}$ & $\begin{array}{c}\text { World Bank } \\
\text { (WDI) }\end{array}$ \\
\hline $\begin{array}{l}\text { Regulation } \\
\text { Quality }\end{array}$ & RQ & $\begin{array}{l}\text { "Regulation quality (estimate): measured as the ability } \\
\text { of the government to formulate and implement sound } \\
\text { policies and regulations that permit and promote private } \\
\text { sector development". }\end{array}$ & $\begin{array}{c}\text { World Bank } \\
\text { (WDI) }\end{array}$ \\
\hline $\begin{array}{l}\text { Corruption- } \\
\text { Control }\end{array}$ & $\mathrm{CC}$ & $\begin{array}{l}\text { "Control of corruption (estimate): captures perceptions } \\
\text { of the extent to which public power is exercised for } \\
\text { private gain, including both petty and grand forms of }\end{array}$ & $\begin{array}{c}\text { World Bank } \\
\text { (WDI) }\end{array}$ \\
\hline
\end{tabular}




\begin{tabular}{|c|c|c|}
\hline Rule of Law & RL & $\begin{array}{l}\text { extent to which agents have confidence in and abide } \\
\text { the rules of society and in particular the quality of } \\
\text { contract enforcement, property rights, the police, the } \\
\text { courts, as well as the likelihood of crime and violence }\end{array}$ \\
\hline Mobile phones & Mobile & Mobile phone subscriptions (per 100 people) \\
\hline GDP growth & GDPg & Gross Domestic Product (GDP) growth (annual \%) \\
\hline $\begin{array}{l}\text { Population } \\
\text { growth }\end{array}$ & Popg & Population growth rate (annual \%) \\
\hline $\begin{array}{l}\text { Foreign } \\
\text { investment }\end{array}$ & FDI & Foreign Direct Investment inflows ( $\%$ of GDP) \\
\hline Foreign aid & Aid & Total Development Assistance (\% of GDP) \\
\hline Private Credit & Credit & $\begin{array}{l}\text { Private credit by deposit banks and other financial } \\
\text { institutions ( } \% \text { of GDP) }\end{array}$ \\
\hline
\end{tabular}

corruption, as well as 'capture' of the state by elites and private interests"

"Rule of law (estimate): captures perceptions of the extent to which agents have confidence in and abide by

World Bank (WDI) contract enforcement, property rights, the police, the courts, as well as the likelihood of crime and violence"

WDI: World Bank Development Indicators.

World Bank (WDI)

World Bank (WDI)

World Bank (WDI)

World Bank (WDI)

World Bank (WDI)

World Bank (WDI)

Appendix 2: Summary statistics (2000-2012)

\begin{tabular}{|c|c|c|c|c|c|c|c|c|}
\hline & Mean & SD & Min & Max & Skewness & $\begin{array}{l}\text { Excess } \\
\text { Kurtosis } \\
\end{array}$ & $\begin{array}{l}\text { Jarque- } \\
\text { bera }\end{array}$ & Obser \\
\hline $\begin{array}{l}\text { Cost of starting } \\
\text { business }\end{array}$ & 156.079 & 219.820 & 0.300 & 1540.2 & 3.734 & 16.376 & $6007 * * *$ & 445 \\
\hline $\begin{array}{l}\text { Contract } \\
\text { enforcement }\end{array}$ & 39.305 & 5.224 & 23.000 & 54.000 & -0.350 & 1.063 & $30.061 * * *$ & 445 \\
\hline $\begin{array}{l}\text { Start-up } \\
\text { procedure }\end{array}$ & 9.856 & 3.005 & 3.000 & 18.000 & 0.383 & 0.794 & $22.624 * * *$ & 445 \\
\hline Ware house time & 195.760 & 98.496 & 48.000 & 599 & 2.015 & 5.457 & 703.779**** & 367 \\
\hline $\begin{array}{l}\text { Time to enforce a } \\
\text { contract }\end{array}$ & 683.024 & 277.839 & 230.000 & 1715 & 1.267 & 2.016 & $194.571 * * *$ & 445 \\
\hline $\begin{array}{l}\text { Time to register a } \\
\text { property }\end{array}$ & 82.592 & 74.197 & 9.000 & 389 & 2.188 & 4.669 & $703.158 * * *$ & 412 \\
\hline $\begin{array}{l}\text { Time to start a } \\
\text { business }\end{array}$ & 49.884 & 43.658 & 5.000 & 260 & 2.070 & 5.140 & $807.689 * * *$ & 445 \\
\hline Time to export & 33.789 & 14.344 & 10 & 78 & 0.844 & 0.169 & $44.992 * * *$ & 375 \\
\hline Time to pay taxes & 319.382 & 196.048 & 66 & 1120 & 1.427 & 2.155 & $199.927 * * *$ & 375 \\
\hline $\begin{array}{l}\text { Resolving an } \\
\text { insolvency }\end{array}$ & 3.094 & 1.129 & 1.7 & 6.2 & 0.809 & -0.210 & $41.323 * * *$ & 372 \\
\hline $\begin{array}{l}\text { Mobile phone } \\
\text { penetration }\end{array}$ & 23.379 & 28.004 & 0.000 & 147.202 & 1.582 & 2.254 & $359.82 * * *$ & 572 \\
\hline Political Stability & -0.543 & 0.956 & -3.323 & 1.192 & -0.473 & -0.440 & $26.204 * * *$ & 578 \\
\hline $\begin{array}{l}\text { Voice \& } \\
\text { Accountability }\end{array}$ & -0.646 & 0.737 & -2.233 & 0.990 & 0.199 & -0.764 & $17.866 * * *$ & 578 \\
\hline $\begin{array}{l}\text { Government } \\
\text { Effectiveness }\end{array}$ & -0.771 & 0.620 & -2.450 & 0.934 & 0.324 & 0.083 & $10.254 * * *$ & 577 \\
\hline
\end{tabular}




\begin{tabular}{|c|c|c|c|c|c|c|c|c|}
\hline $\begin{array}{l}\text { Regulation } \\
\text { Quality }\end{array}$ & -0.715 & 0.644 & -2.665 & 0.983 & -0.234 & 0.508 & $11.475 * * *$ & 578 \\
\hline $\begin{array}{l}\text { Corruption- } \\
\text { Control }\end{array}$ & -0.642 & 0.591 & -1.924 & 1.249 & 0.683 & 0.198 & $45.855 * * *$ & 579 \\
\hline Rule of Law & -0.741 & 0.662 & -2.668 & 1.056 & 0.192 & 0.117 & 3.905 & 578 \\
\hline GDP growth & 4.714 & 6.322 & -47.552 & 63.379 & 1.949 & 21.780 & $12321 * * *$ & 608 \\
\hline $\begin{array}{l}\text { Population } \\
\text { growth }\end{array}$ & 2.361 & 0.948 & -1.081 & 6.576 & -0.432 & 1.803 & $96.051 * * *$ & 588 \\
\hline $\begin{array}{l}\text { Foreign Direct } \\
\text { Investment } \\
\text { inflows }\end{array}$ & 5.332 & 8.737 & -6.043 & 91.007 & 5.054 & 37.100 & $37150 * * *$ & 603 \\
\hline Foreign aid & 11.687 & 14.193 & -0.253 & 181.187 & 5.373 & 47.653 & $60054 * * *$ & 606 \\
\hline $\begin{array}{l}\text { Private Domestic } \\
\text { Credit }\end{array}$ & 18.551 & 22.472 & 0.550 & 149.78 & 3.711 & 15.985 & $6561 * * *$ & 507 \\
\hline
\end{tabular}


Appendix 3: Correlation matrix (uniform sample size: 247)

\begin{tabular}{|c|c|c|c|c|c|c|c|c|c|c|c|c|c|c|c|c|c|c|c|c|c|c|}
\hline $\begin{array}{l}\text { Cost- } \\
\text { ostart }\end{array}$ & $\begin{array}{l}\text { Contra- } \\
\text { ctenf }\end{array}$ & $\begin{array}{l}\text { Startup- } \\
\text { proced }\end{array}$ & $\begin{array}{l}\text { Timewa } \\
\text { rehouse }\end{array}$ & $\begin{array}{l}\text { Timen } \\
\text { forcontr }\end{array}$ & $\begin{array}{l}\text { Time } \\
\text { regprop }\end{array}$ & $\begin{array}{l}\text { Time } \\
\text { startbus }\end{array}$ & $\begin{array}{l}\text { Time } \\
\text { xport }\end{array}$ & $\begin{array}{l}\text { Time } \\
\text { taxes }\end{array}$ & $\begin{array}{l}\text { Timere } \\
\text { sinsolv }\end{array}$ & Pols & VA & GE & $\mathrm{RQ}$ & $\mathrm{CC}$ & RL & GDPg & Popg & FDI & Aid & Credit & Mobile & \multirow[b]{2}{*}{ Costostart } \\
\hline \multirow[t]{22}{*}{1.000} & 0.218 & 0.220 & 0.092 & -0.068 & 0.263 & 0.028 & 0.317 & 0.157 & 0.214 & -0.258 & -0.274 & $\begin{array}{c}-0.473 \\
\end{array}$ & $\begin{array}{l}-0.424 \\
\end{array}$ & -0.416 & $\begin{array}{l}-0.395 \\
\end{array}$ & 0.067 & 0.353 & -0.044 & 0.263 & -0.309 & -0.396 & \\
\hline & 1.000 & 0.134 & -0.005 & 0.041 & 0.088 & 0.043 & 0.238 & 0.288 & 0.264 & -0.520 & -0.430 & -0.555 & -0.630 & -0.597 & -0.559 & 0.005 & 0.197 & 0.146 & 0.119 & -0.407 & -0.330 & Contractenf \\
\hline & & 1.000 & 0.013 & -0.161 & -0.056 & 0.359 & 0.255 & 0.048 & 0.086 & -0.232 & -0.266 & -0.155 & -0.152 & -0.196 & -0.215 & 0.071 & 0.057 & -0.138 & -0.117 & -0.251 & -0.255 & Startupproced \\
\hline & & & 1.000 & 0.133 & 0.286 & 0.121 & 0.010 & -0.007 & 0.111 & -0.081 & -0.157 & -0.180 & -0.143 & -0.197 & -0.151 & -0.169 & -0.083 & -0.078 & -0.154 & -0.249 & -0.077 & Timewarehouse \\
\hline & & & & 1.000 & -0.136 & 0.278 & -0.238 & -0.104 & 0.208 & 0.157 & -0.0009 & -0.027 & -0.120 & 0.031 & -0.001 & 0.045 & -0.131 & 0.317 & 0.325 & -0.038 & 0.066 & Timenforcontr \\
\hline & & & & & 1.000 & -0.045 & -0.070 & 0.073 & -0.004 & -0.008 & -0.056 & -0.192 & -0.082 & -0.150 & -0.076 & -0.064 & 0.044 & -0.146 & 0.023 & -0.095 & -0.246 & Timeregprop \\
\hline & & & & & & 1.000 & 0.050 & 0.145 & 0.206 & 0.183 & -0.043 & -0.041 & -0.136 & 0.017 & -0.028 & -0.035 & -0.228 & 0.201 & 0.031 & -0.074 & 0.035 & Timestartbus \\
\hline & & & & & & & 1.000 & 0.187 & 0.312 & -0.378 & -0.339 & -0.413 & -0.400 & -0.382 & -0.401 & 0.126 & 0.293 & -0.097 & -0.008 & -0.339 & -0.519 & Timexport \\
\hline & & & & & & & & 1.000 & 0.195 & -0.332 & -0.275 & -0.335 & -0.247 & -0.413 & -0.403 & -0.036 & 0.113 & -0.039 & -0.171 & -0.154 & -0.103 & Timetaxes \\
\hline & & & & & & & & & 1.000 & -0.111 & -0.142 & -0.381 & -0.326 & -0.383 & -0.369 & -0.016 & 0.240 & 0.093 & 0.194 & -0.241 & -0.271 & Timeresinsolv \\
\hline & & & & & & & & & & 1.000 & 0.692 & 0.678 & 0.635 & 0.727 & 0.795 & -0.053 & -0.289 & 0.033 & -0.101 & 0.286 & 0.399 & PolS \\
\hline & & & & & & & & & & & 1.000 & 0.797 & 0.757 & 0.745 & 0.808 & 0.097 & -0.143 & 0.013 & 0.017 & 0.524 & 0.324 & VA \\
\hline & & & & & & & & & & & & 1.000 & 0.875 & 0.888 & 0.915 & 0.0001 & -0.415 & -0.148 & -0.262 & 0.618 & 0.484 & $\mathrm{GE}$ \\
\hline & & & & & & & & & & & & & 1.000 & 0.811 & 0.859 & -0.038 & -0.239 & -0.210 & -0.299 & 0.607 & 0.426 & RG \\
\hline & & & & & & & & & & & & & & 1.000 & 0.894 & -0.022 & -0.432 & -0.116 & -0.210 & 0.521 & 0.451 & $\mathrm{CC}$ \\
\hline & & & & & & & & & & & & & & & 1.000 & 0.011 & -0.307 & -0.089 & -0.174 & 0.496 & 0.422 & RL \\
\hline & & & & & & & & & & & & & & & & 1.000 & 0.244 & 0.189 & 0.300 & -0.100 & -0.152 & GDPg \\
\hline & & & & & & & & & & & & & & & & & 1.000 & 0.139 & 0.479 & -0.406 & -0.450 & Popg \\
\hline & & & & & & & & & & & & & & & & & & 1.000 & 0.423 & -0.102 & 0.022 & FDI \\
\hline & & & & & & & & & & & & & & & & & & & 1.000 & -0.172 & -0.264 & Aid \\
\hline & & & & & & & & & & & & & & & & & & & & 1.000 & 0.464 & Credit \\
\hline & & & & & & & & & & & & & & & & & & & & & 1.000 & Mobile \\
\hline
\end{tabular}

Costostart: cost of business start-up procedure. Contractenf: Procedure to enforce a contract. Startupproced: Start-up procedures to register a business. Timewarehouse: Time required to build a warehouse.

Timenforcontr : Time required to enforce a contract. Timeregroup: Time required to register a property. Timestartbus : Time required to start a business. Timexport: Time to export. Timetaxes: Time to prepare and pay

taxes. Timeresinsolv : Time to resolve insolvency. PolS: Political Stability. VA: Voice \& Accountability. GE: Government Effectiveness. RQ: Regulation Quality. CC: Corruption-Control. RL: Rule of Law. GDPg:

GDP growth. Popg: Population growth. FDI: Foreign Direct Investment inflows. Aid: Foreign aid. Credit: Private domestic credit. Mobile: Mobile Phone penetration 


\section{Appendix 4: Persistence outcome variables}

\begin{tabular}{|c|c|c|c|c|c|c|c|c|c|c|}
\hline & $\begin{array}{l}\text { Cost- } \\
\text { ostart }\end{array}$ & $\begin{array}{l}\text { Contra- } \\
\text { ctenf }\end{array}$ & $\begin{array}{l}\text { Startup- } \\
\text { proced }\end{array}$ & $\begin{array}{l}\text { Timeware- } \\
\text { house }\end{array}$ & $\begin{array}{l}\text { Timen- } \\
\text { forcontr }\end{array}$ & $\begin{array}{l}\text { Time- } \\
\text { regprop }\end{array}$ & $\begin{array}{l}\text { Time- } \\
\text { startbus }\end{array}$ & $\begin{array}{l}\text { Time- } \\
\text { xport }\end{array}$ & $\begin{array}{l}\text { Time- } \\
\text { taxes }\end{array}$ & $\begin{array}{l}\text { Time- } \\
\text { resinsolv }\end{array}$ \\
\hline Costostart (-1) & 0.9284 & & & & & & & & & \\
\hline Contractenf $(-1)$ & & 0.9970 & & & & & & & & \\
\hline Startupproced (-1) & & & 0.9400 & & & & & & & \\
\hline Timewarehouse (-1) & & & & 0.9640 & & & & & & \\
\hline Timenforcontr $(-1)$ & & & & & 0.9883 & & & & & \\
\hline Timeregprop (-1) & & & & & & 0.9187 & & & & \\
\hline Timestartbus (-1) & & & & & & & 0.9263 & & & \\
\hline Timexport (-1) & & & & & & & & 0.9767 & & \\
\hline Timetaxes $(-1)$ & & & & & & & & & 0.9923 & \\
\hline Timeresinsolv (-1) & & & & & & & & & & 0.9997 \\
\hline
\end{tabular}

Costostart: cost of business start-up procedure. Costostart (-1): lagged cost of business start-up procedure. Contractenf: Procedure to enforce a contract. Startupproced: Start-up procedures to register a business. Timewarehouse: Time required to build a warehouse. Timenforcontr : Time required to enforce a contract. Timeregroup: Time required to register a property. Timestartbus : Time required to start a business. Timexport: Time to export. Timetaxes: Time to prepare and pay taxes. Timeresinsolv : Time to resolve insolvency. 


\section{References}

Acs, Z. J., \& Sanders, M. (2012). "Patents, knowledge spillovers, and entrepreneurship". Small Business Economics, 39(4), pp. 801-817.

African Economic Research Consortium (AERC, 2014). "Youth Employment: Opportunities and Challenges", $40^{\text {th }}$ Plenary Session of the AERC's Biannual Research Workshop, Lusaka, Zambia (November, $30^{\text {th }}$ ).

http://aercafrica.org/index.php/news-events/212-aerc-biannual-workshop-climate-change-andeconomic-development-2 (Accessed: 06/01/2015).

Afutu-Kotey, R. L., Gough, K. W., \& Owusu, G., (2017). "Young Entrepreneurs in the Mobile Telephony Sector in Ghana: From Necessities to Aspirations", Journal of African Business, DOI: 10.1080/15228916.2017.1339252.

Ajide, K. B., \& Raheem, I. D., (2016). "Institutions-FDI Nexus in ECOWAS Countries", Journal of African Business, 17(3), pp. 319-341.

Alagidede, P., (2008). “African Stock Market Integration: Implications for Portfolio Diversification and International Risk Sharing”, Proceedings of the African Economic Conferences 2008, Tunis.

Alan Gelb , Taye Mengistae, Ramachandran, V., \& Shah, M. K., (2009). "To Formalize or not to Formalize? Comparisons of Microenterprise Data from Southern and East Africa", CGD Working Paper No. 175, Center for Global Development, Washington.

Alkemade, F., \& Surrs, R. A. A., (2012). "Patterns of expectations for emerging sustainable technologies", Technological Forecasting \& Social Change, 79(3), pp. 448-456.

Allen, T. J., Gloor, P. A., Colladon, A. F., Woerner, S. L., \& Raz, O., (2016). "The power of reciprocal knowledge sharing relationships for startup success", Journal of Small Business and Enterprise Development, 23(3), pp. 636-651.

Amankwah-Amoah, J., (2015). "Solar energy in sub-Saharan Africa: The challenges and opportunities of technological leapfrogging”. Thunderbird International Business Review, 57(1), pp. 15-31.

Amankwah-Amoah, J., (2016). "Global business and emerging economies: Towards a new perspective on the effects of e-waste". Technological Forecasting and Social Change, 105 (April), pp. 20-26.

Amankwah-Amoah, J., \& Sarpong, D., (2016). "Historical pathways to a green economy: The evolution and scaling-up of solar PV in Ghana, 1980-2010". Technological Forecasting and Social Change, 102(January), pp. 90-101.

Amavilah, V., Asongu, S.A., \& Andrés, A. R., (2017). "Effects of globalization on peace and stability: Implications for governance and the knowledge economy of African countries", Technological Forecasting and Social Change, 122(September), pp. 91-103. 
Andrés, R. A, Asongu, S. A., \& Amavilah, V. H., (2015). "The Impact of Formal Institutions on Knowledge Economy”, Journal of the Knowledge Economy, 6(4), pp. 1034-1062.

Anyanwu, J., \& Erhijakpor, A., (2014). "Does Oil Wealth Affect Democracy in Africa?"African Development Review, 26(1), pp. 15-37.

Arellano, M., \& Bond, S., (1991), "Some tests of specification for panel data: Monte Carlo evidence and an application to employment equations" The Review of Economic Studies, 58(2), pp. 277-297.

Arellano, M., \& Bover, O., (1995), "Another look at the instrumental variable estimation of error components models", Journal of Econometrics, 68(1), pp. 29-52.

Asongu, S. A., (2013). "How Would Population Growth Affect Investment in the Future? Asymmetric Panel Causality Evidence for Africa", African Development Review, 25(1), pp. 14-29.

Asongu, S. A., (2015). "Conditional Determinants of Mobile Phones Penetration and Mobile Banking in Sub-Saharan Africa", Journal of the Knowledge Economy. DOI: $10.1007 \% 2 F s 13132-015-0322-\mathrm{z}$.

Asongu, S. A., \& Biekpe, N., (2017). "Mobile Phone Innovation and Entrepreneurship in Sub-Saharan Africa”, African Governance and Development Institute Working Paper No. 17/023, Yaoundé.

Asongu, S. A., Boateng, A., \& Akamavi, R., (2016). "Mobile Phone Innovation and Inclusive Human Development: Evidence from Sub-Saharan Africa", African Governance and Development Institute Working Paper, No. 16/027, Yaoundé.

Asongu, S. A, \& De Moor, L., (2017). "Financial Globalisation Dynamic Thresholds for Financial Development: Evidence from Africa", European Journal of Development Research: 29(1), pp. 192-212.

Asongu, S. A., \& Le Roux, S., (2017). "Enhancing ICT for inclusive human development in Sub-Saharan Africa", Technological Forecasting and Social Change, 118 (May), pp. 44-54.

Asongu, S. A., \& Nwachukwu, J. C., (2016a). "The Role of Governance in Mobile Phones for Inclusive Human Development in Sub-Saharan Africa", Technovation, 55-56(SeptemberOctober), pp. 1-13.

Asongu, S. A, \& Nwachukwu, J. C., (2016b). "The Mobile Phone in the Diffusion of Knowledge for Institutional Quality in Sub Saharan Africa", World Development, 86(October), pp. 133-147.

Asongu, S. A, \& Nwachukwu, J. C., (2016c). "Foreign aid and governance in Africa", International Review of Applied Economics, 30(1), pp. 69-88.

Asongu, S. A., \& Nwachukwu, J. C., (2018). “Openness, ICT and Entrepreneurship in SubSaharan Africa", Information Technology \& People. DOI: 10.1108/ITP-02-2017-0033. 
Asongu, S. A., \& Tchamyou, V. S., (2016). "The impact of entrepreneurship on knowledge economy in Africa", Journal of Entrepreneurship in Emerging Economies, 8(1), pp. 101- 131.

Asongu, S. A., Anyanwu, J.C., \& Tchamyou, V. S., (207). "Technology-driven information sharing and conditional financial development in Africa", Information Technology for Development. DOI: 10.1080/02681102.2017.1311833.

Baltagi, B. H., (2008). "Forecasting with panel data", Journal of Forecasting, 27(2), pp. 153173.

Bardy, R., Drew, S., \& Kennedy, T. F., (2012). "Foreign Investment and Ethics: How to Contribute to Social Responsibility by Doing Business in Less-Developed Countries", Journal of Business Ethics, 106(3), pp. 267-282.

Baumol, W. J., (1968). "Entrepreneurship in Economic Theory”. American Economic Review, Papers and Proceedings, 58(2), pp. 64-71.

Baumol, W.J. (1990). "Entrepreneurship: Productive, Unproductive and Destructive". Journal of Political Economy, 985(5), pp. 893-921.

Baumol, W.J. (2010). The Micro-Theory of Innovative Entrepreneurship, Princeton: Princeton University Press.

Beck, T., Demirgüç-Kunt, A., \& Levine, R., (2003), "Law and finance: why does legal origin matter?", Journal of Comparative Economics, 31(4), pp. 653-675.

Best, M.H., (2015). "Greater Boston's industrial ecosystem: a manufactory of sectors". Technovation, 39-40 (2015), pp. 4-13.

Blundell, R., \& Bond, S., (1998). "Initial conditions and moment restrictions in dynamic panel data models" Journal of Econometrics, 87(1), pp. 115-143.

Boateng, A., Asongu, S. A., Akamavi, R., \& Tchamyou, V. S., (2016). "Information Asymmetry and Market Power in the African Banking Industry", African Governance and Development Institute Working Paper No. 16/032, Yaoundé.

Bond, S., Hoeffler, A., \& Tample, J. (2001) "GMM Estimation of Empirical Growth Models", University of Oxford.

Boulianne, S., (2009). "Does Internet Use Affect Engagement? A Meta-Analysis of Research", Political Communication, 26(2), pp. 193-211.

Breuer, A., Landmann, T., \& Farquhar, D., (2012). "Social media and protest mobilization: evidence from the Tunisian revolution”, Democratization, 22(4), pp. 764-792.

Brixiová, Z., (2010). "Unlocking Productive Entrepreneurship in Africa's Least Developed Countries". African Development Review, 22(3), pp. 440-451. 
Brixiová, Z., (2013). "Modelling Productive Entrepreneurship in Developing Countries". Small Business Economics, 41(1), pp. 183-194.

Brixiová, Z., Ncube, N., \& Bicaba, Z., (2015). "Skills and Youth Entrepreneurship in Africa: Analysis with Evidence from Swaziland", World Development, 67(C), pp. 11-26.

Brixiova Z., Ncube, M. \& Bicaba, Z., (2015). "Skills and Youth Entrepreneurship in Africa: Analysis with Evidence from Swaziland", World Development, 67(3), pp.11-26.

Brouwer, R., \& Brito, L., (2012). "Cellular phones in Mozambique: Who has them and who doesn't?”, Technological Forecasting \& Social Change, 79(2), pp. 231-243.

Coleman, J. S., (1988). "Social capital in the creation of human capital", American Journal of Sociology, 94, (1998), pp. S95-S120.

Daouda, F.B., Ingenbleek, P.T. M., \& Van Trijp, H. C.M., (2016). "Step-Change: MicroEntrepreneurs' Entry into the Middle-Class Market", Journal of African Business, 17(2), pp. 129-147.

Diamond, L., (2010). “Liberation Technology”, Journal of Democracy, 21(3), pp. 69-83.

Du, M., \& Boateng., A (2015). "State ownership, institutional effects and value creation in cross-border mergers and acquisitions by Chinese firms", International Business Review, 24(3), pp. 430-442

Eifert, B., Gelb, A., \& Ramachandran, V., (2008). "The Cost of Doing Business in Africa: Evidence from Enterprise Survey Data”, World Development, 36(9), pp. 1531-1546.

Efobi, U., (2015). "Politicians' Attributes and Institutional Quality in Africa: A Focus on Corruption", Journal of Economic Issues, 49(3), pp. 787-813.

Elhorst, J. P. (2003). "The Mystery of Regional Unemployment Differentials: Theoretical and Empirical Explanations”. Journal of Economic Surveys, 17(5), pp. 709-748.

Ernst \& Young (2013). "Doing business in Africa: From strategy to execution", Growing Beyond http://www.ey.com/Publication/vwLUAssets/Doing_business_in_Africa__From_strategy_to_execution/\$FILE/130130\%20SGF\%20Thought\%20Leadership\%20email \%2 0version.pdf (Accessed : 07/12/2013).

Fonchingong, C., (2014). "Firming Up Institutional Policy for Deprived Elderly in Cameroon", Politics \& Policy, 42(6), pp. 948-980.

Fosu, A., (2013a), "Growth of African Economies: Productivity, Policy Syndromes and the Importance of Institutions" Journal of African Economies, 22(4), pp. 523-551.

Fosu, A., (2013b). "Growth of African Economies: Productivity, Policy Syndromes and the Importance of Institutions" Journal of African Economies 22(4), pp. 523-551. 
Fosu, A., (2015a). Growth and Institutions in African Development, First edited by Augustin K. Fosu, Routledge Studies in Development Economics: New York

Fosu, A., (2015b). Growth and institutions in African Development, in Growth and Institutions in African Development, First edited by Augustin K. Fosu, 2015, Chapter 1, pp. 1-17, Routledge Studies in Development Economics: New York.

Gani, A., (2011). “Governance and Growth in Developing Countries", Journal of Economic Issues, 45(1), pp. 19-40.

Gerba, D. T. (2012). "Impact of entrepreneurship education on entrepreneurial intentions of business and engineering students in Ethiopia", African Journal of Economic and Management Studies, 3(2), pp. 258-277.

Ghio, N., Guerini, M., Lehmann, E.E., \& Rossi-Lamastra, C., (2015). "The emergence of the knowledge spillover theory of entrepreneurship" , Small Business Economics, 44(1), pp. 1-18

Grossman, G., Humphreys, M., \& Sacramone-Lutz, G., (2014). “"II wld like u WMP to extend electricity 2 our village": On Information Technology and Interest Articulation", American Political Science Review, 108(3), pp. 688-705.

Gupta, R., \& Jain, K., (2012). "Diffusion of mobile telephony in India: An empirical study", Technological Forecasting \& Social Change, 79(4), pp. 709-715.

Hang, C.C., Garnsey, E., \& Ruan, Y., (2015). “Opportunities for disruption”. Technovation 39-40 (2015), pp. 83-93.

Hayter, C. S. (2013). "Conceptualizing knowledge-based entrepreneurship networks: Perspectives from the literature”. Small Business Economics, 41(4), pp. 899-911.

Hellstrom, J. (2008), "Mobile phones for good governance- challenges and way forward", Stockholm University / UPGRAID, http://www.w3.org/2008/10/MW4D_WS/papers/hellstrom_gov.pdf (Accessed: 22/11/2015).

Howells, J. (2005). "Innovation and Regional Economic development: A matter of perspective", Research Policy, 34(8), pp. 1220-1234.

Islama, T., \& Meadeb, N., (2012). "The impact of competition, and economic globalization on the multinational diffusion of 3G mobile phones", Technological Forecasting \& Social Change, 79(5), pp. 843-850.

Jeong, Y., \& Yoon, B., (2015). "Development of patent roadmap based on technology roadmap by analyzing patterns of patent development". Technovation, 39-40 (2015), pp. 37-52.

Jones, N., Borgman, R., Ulusoy, E., (2015). "Impact of social media on small businesses", Journal of Small Business and Enterprise Development, 22(4), pp.611-632. 
Kaufmann, D., Kraay, A \& Mastruzzi, M., (2010). “The worldwide governance indicators: Methodology and analytical Issues". World Bank Policy Research Working Paper No 5430, Washington.

Khavul, S., Bruton, J. D., \& Wood, E., (2009). "Informal Family Business in Africa", Entrepreneurship: Theory \& Practice, 33(6), pp. 1219-1238.

Kohlbacher, F., Herstatt, C., \& Levsen, N., (2015). “Golden opportunities for silver innovation: how demographic changes give rise to entrepreneurial opportunities to meet the needs of older people". Technovation , 39-40 (2015), pp. 73-82.

Korenman, S., \& Neumark, D., (2000). "Cohort Crowding and Youth Labour Markets: A Cross National Analysis". In D.G. Blanch flower, and R.B. Freeman (eds), Youth Employment and Joblessness in Advanced Countries. Chicago: University of Chicago Press.

Kramon, E., (2009). "Vote Buying and Turnout in Kenya's 2002 Elections", University of California, Los Angeles, http://www.sscnet.ucla.edu/polisci/wgape/papers/17_Kramon.pdf (Accessed: 23/08/2015).

Kuada, J. (2014). "Cross- border interfirm knowledge generation and enterprise development in Africa", in Nwankwo, S. and Ibeh, K. (Eds), The Routledge Companion to Business in Africa, Routledge, London and New York, pp. 352-370.

Kuada, J., (2015), "Entrepreneurship in Africa - a classificatory framework and a research agenda", African Journal of Economic and Management Studies, 6(2) pp. 148-163.

Kuada, J., (2009). "Gender, social networks, and entrepreneurship in Ghana", Journal of African Business, 10 (1), pp. 85-103.

Leff, N. H. (1979). "Entrepreneurship and Economic Development: The Problem Revisited". Journal of Economic Literature, 17(1), pp. 46-64.

Leke, A., Lund, S., Roxburgh, C., \& Van Wamelen, A., (2010). "What's driving Africa's growth", McKinsey \& Company report.

http://www.mckinsey.com/insights/economic_studies/whats_driving_africas_growth (Accessed: 31/03/2014)

Love, I., \& Zicchino, L., (2006). "Financial Development and Dynamic Investment Behaviour: Evidence from Panel VAR". The Quarterly Review of Economics and Finance, 46(2), pp. 190-210.

Manacorda, M., \& Tesei, A., (2016). "Liberation Technology: Mobile Phones and Political Mobilization in Africa", Queen Mary University of London, http://personal.lse.ac.uk/manacorm/liberation_technology.pdf (Accessed: 20/02/2016).

Maine, E., Soh, P.-H., \& Dos Santos, N., (2015). "The role of entrepreneurial decision making in opportunity creation and recognition". Technovation, 39-40(2015), pp. 53-72. 
McCann, M., \& Barlow, A., (2015). "Use and measurement of social media for SMEs", Journal of Small Business and Enterprise Development, 22(2), pp.273-287.

McKelvey, M., Zaring, O., Ljungberg, D., 2015. Creating innovative opportunities through research collaboration: an evolutionary framework and empirical illustration in engineering. Technovation 39-40(2015), pp. 26-36.

Mensah, S. N., \& Benedict, E., (2010). "Entrepreneurship training and poverty alleviation: Empowering the poor in the Eastern Free State of South Africa", African Journal of Economic and Management Studies, 1(2), pp. 138-163.

Meyer KE, Estrin S., Bhaumik SK, \& Peng M., W. (2009). "Institutions, resources, and entry strategies in emerging economies". Strategic Management Journal, 30(1), pp. 61-80.

Myers, J.W. \& Rowan, B., (1977). Institutionalised organisations: Formal structure as myth and ceremony, American Journal of Sociology, 83(2), pp. 340-363.

Mira, M., \& Dangersfield, B., (2012). "Propagating a digital divide: Diffusion of mobile telecommunication services in Pakistan", Technological Forecasting \& Social Change, 79(3), pp. 448-456.

Mpogole, H., Usanga, H., \& Tedre, M., (2008). "Mobile phones and poverty alleviation: a survey study in rural Tanzania", Proceedings of M4D 2008, Karlstad University, Sweden, pp. 62-72.

Mulloth, B., Kickul, J. R., \& Gundry, L. K., (2016). "Driving technology innovation through social entrepreneurship at Prezi", Journal of Small Business and Enterprise Development, 23(3), pp. 753-767.

Naudé, W., (2008). "Entrepreneurship in Economic Development". WIDER Research Paper No. 2008/20. UNU-WIDER, Helsinki.

Naudé, W., (2010). "Promoting Entrepreneurship in Developing Countries: Policy Challenges". UNU-WIDER Policy Brief No. 4, Helsinki.

O’Higgins, N., (2001). Youth Unemployment and Employment Policy: A Global Perspective. Geneva: ILO.

Oliver, C., (1991). "Strategic responses to institutional processes", The Academy of Management Review, 16(1), pp. 145-179.

Oliver, C., (1997). "Sustainable competitive advantage: Combining institutional and resource based views", Strategic Management Journal, 18 (9), pp. 697-713.

Oluwatobi, S., Efobi, U.R., Olurinola, O.I., Alege, P. (2015), "Innovation in Africa: Why Institutions Matter", South African Journal of Economics, 83(3), pp. 390-410.

Oseifuah, E. K., (2010). "Financial literacy and youth entrepreurship in South Africa", African Journal of Economic and Management Studies, 1(2), pp. 164-182. 
Overholm, H., (2015). "Collectively created opportunities in emerging ecosystems: the case of solar service ventures". Technovation, 39-40(2015), pp.14-25.

Paul, B., Bhorat, H., \& Cheadle, H., (2010). "The cost of "doing business and labour regulation: The case of South Africa”, International Labour Review, 149(1), pp. 73-91.

Penard, T., Poussing, N., Yebe, G. Z., \& Ella, P. N., (2012). "Comparing the Determinants of Internet and Cell Phone Use in Africa: Evidence from Gabon ", Communications \& Strategies, 86(2), pp. 65-83.

Peng, W.M. (2003a). "Institutional Transition and Strategic choices", Academy of Management Review, 28(2), pp. 275-296.

Peng, W.M. (2003b). “Towards an institution-based view of business strategy", Asia Pacific Journal of Management, 19 (1-2), pp. 251-267.

Peterson, G. E., \& Vroman, W., (1992). Urban Labour Markets and Job Opportunity. Washington, DC: The Urban Institute Press.

Pierskalla, J. H., \& Hollenbach, F. M., (2013). "Technology and Collective Action: The Effect of Cell Phone Coverage on Political Violence in Africa", American Political Science Review, 107(2), pp. 207-224.

Rogerson, C. M. (2001). "In Search of the African Miracle: Debates on Successful Small Enterprise Development in Africa". Habitat International, 25(1), pp. 115-142.

Roodman, D., (2009a). "A Note on the Theme of Too Many Instruments", Oxford Bulletin of Economics and Statistics, 71(1), pp. 135-158.

Roodman, D., (2009b). "How to do xtabond2: An introduction to difference and system GMM in Stata”, Stata Journal, 9(1), pp. 86-136.

Scott, W.R. (2001). Institutions and organisations (2nd ed.). Thousand Oaks, CA: Sage

Scott,W. R. (2002). The changing world of Chinese enterprises: An institutional perspective. In A.S.Tsui C.-M.Lau(Eds.), Management of enterprises in the People's Republic of China (pp. 59-78).Boston: Kluwer Academic Press.

Singh, S., Simpson, R., Mordi, C., \& Okafor, C., (2011). "Motivation to become an entrepreneur : a study of Nigerian women's decisions", African Journal of Economic and Management Studies, 2(2), pp. 202-219.

Solow, R. M. (1994). Perspectives on Economic growth theory", Journal of Economic Perspectives, 8(1), 45-54.

Sonne, L., (2012). "Innovative initiatives supporting inclusive innovation in India: Social business incubation and micro venture capital”, Technological Forecasting \& Social Change, 79(4), pp. 638-647. 
Suarez, S. L., (2006). "Mobile democracy: text messages, voter turnout and the 2004 Spanish general election", Representation, 42(2), pp. 117-128.

Taplin, R., \& Snyman, M., (2004). "Doing business in South Africa's new mining environment: A legal perspective”, CIM Bulletin, 97(1078), pp. 91-98.

Tapsoba, S. J-A., (2010). "Trade Intensity and Business Cycle Synchronicity in Africa", African Development Review, 22(1), pp. 149-172.

Tchamyou, V. S., (2016). "The role of knowledge economy in African business", Journal of the Knowledge Economy. DOI: 10.1007/s13132-016-0417-1.

Tchamyou, V. S., \& Asongu, S. A., (2017). "Information Sharing and Financial Sector Development in Africa", Journal of African Business, 18(1), pp. 24-49.

Thakar, D., (2012). "Market competition and the distributional consequences of mobile phones in Canada", Technological Forecasting \& Social Change, 79(2), pp. 223-230.

Wan, F., Williamson, P.J., \& Yin, E., (2015). "Antecedents and implications of disruptive innovation: evidence from China”. Technovation, 39-40(2015), pp. 94-104.

United Nations (2009). "Worlds Population Prospects”. United Nations.

Wang, Y., (2016). "Investigating dynamic capabilities of family businesses in China: a social capital perspective", Journal of Small Business and Enterprise Development, 23(4), pp. 10571080.

Weidmann, J. N., \& Shapiro, N. B., (2015). "Is the Phone Mightier Than the Sword?

Cellphones and Insurgent Violence in Iraq", International Organisation, 69(2), pp. 247-274.

Yerrabati, S., \& Hawkes, D., (2015). "Economic Governance and Economic Growth in South and East Asia \& Pacific Region: Evidence from Systematic Literature Reviews and Metaanalysis". Advances in Economics and Business, 3(1), pp. 1- 21. 